Józef Matuszewski

\title{
Prawo sądowe na wsi polskiej lokowanej na prawie niemieckim*
}

\section{Das Gerichtsrecht im polnischen, deutschrechtlichen Dorf}

1. Zasada osobowości praw a kolonizacja. 2. Reforma rolna a recepcja prawa niemieckiego. 3. Znajomość prawa niemieckiego wśród ludności polskiej. 4. Kto był zainteresowany recepcją prawa niemieckiego? 5. Wieloznaczność terminologii źródeł. 6. Wieloznaczność wyrażenia ius teutonicum. 7. Sądownictwo poimmunitetowe na wsi polskiej. 8. Recepcja prawa niemieckiego przez polskich chłopów. 9. Kwestie rozpatrywane w sądach wiejskich. 10. Skład ławy we wsiach polskich. 11. Społeczność wiejska zlożona z Niemców i Polaków. 12. Konflikt praw. 13. Rzekoma niemieckość wiejskiej procedury sądowej. 14. Rzekoma niemieckość wiejskiego prawa materialnego. 15. Nieznajomość prawa niemieckiego a złudzenie poshugiwania się nim. 16. Wnioski.

1. Personalitätsprinzip und deutschrechtliche Siedlung. 2. Agrarreform und Aufnahme des deutschen Rechts. 3. Hat die polnische Bevölkerung das deutsche Recht gekannt? 4. Wer hatie Interesse für das deutsche Recht? 5. Vieldeutigkeit der Quellenterminologie. 6. Vieldeutigkeit des Terminus: ius Teutonicum. 7. Gerichtsverfassung in den immunisierten polnischen Dörfern. 8. Aufnahme des deutschen Rechts durch polnische Bauern. 9. Womit beschäftigten sich die Dorfgericht? 10. Zusammensetzung der Schöffenbank in den polnischen Dörfern. 11. Gemischte, polnische und deutsche Bevölkerung. 12. Rechtskonflikte. 13. War der Rechtsgang in den Dorfgerichten wirklich deutsch? 14. Bediente man sich dort des deutschen materiellen Rechts? 15. In der Tat blieb das deutsche Recht dem polnischen Bauer unbekannt. 16. Schlußfolgerungen.

* Zastosowane skróty: APH - Acta Poloniae Historica; CPH - "Czasopismo Prawno-Historyczne"; KDW - Kodeks Dyplomatyczny Wielkopolski; Komb. - Ksiega gromadzka wsi Kombornia 1457-1683, SPPP, t. 11, (Kraków 1921), s. 3-65; Kroś. - Księgi gromadzkie wsi Krościenko 1408-1535, SPPP, t. 11, s. 147-273; Krzem. - Das Schöffenbuch der Dorfgemeinde Krzemienica aus den Jahren 1454-1482, herausgegeben, eingeleitet und bearbeitet von F. A. Doubek und H. F. Schmid, Leipzig 1931; Ks. Henr. - Liber fundationis claustri sanctae Mariae Virginis in Heinrichow, red. J. Matuszewski, S. Rospond, Poznań 1949; L.b. Liber beneficiorum; Maszk. - Ksiega gromadzka wsi Maszkienice 1482-1602, SPPP, t. 11, s. 69-144; Menzel - Die schlesischen Lokationsurkunden des 13. Jahrhunderts, Würzburg 1977; PH - „Przegląd Historyczny”; PSB - Polski Slownik Biograficzny; RKJ - „Rozprawy Komisji Językowej”; SIStp - Slownik Staropolski; SUb - Schlesisches Urkundenbuch 1-4, hrsg. v. H. Appelt, W. Irgang; SPPP - Starodawne prawa polskiego pomniki; T. - Najstarsza ksiega sqdowa wsi Trześniowa 1419-1609, wyd. H. Polaczkówna, Lwów 1923; Wara - Ksiega sqdowa wsi Wara 1449-1623, wyd. L. Lysiak, Wrocław 1971. 


\section{A}

1.1. Nasi prawnicy przedrozbiorowi przeciwstawiali prawu politycznemu prawo sądowe (ius iudiciarium), pod którym rozumieli te dziedziny prawa, które mają bezpośredni związek $\mathrm{z}$ wymiarem sprawiedliwości, a więc ustrój sądów, prawo prywatne i karne oraz procedurę ${ }^{1}$. Zachowamy owo wyrażenie w dalszych wywodach, mimo że nie spotkaliśmy go nigdy w przywilejach lokacyjnych prawa niemieckiego ${ }^{2}$. Okazuje się ono przydatne, precyzuje bowiem dokładnie zagadnienie, którym w przedstawianym artykule zamierzamy się zająć.

1.2. Pamiętać musimy wszakże o jednym. W średniowieczu o wszystkim decydowal zwyczaj, consuetudo, zarówno w prawie państwowym, jak i w prawie prywatnym. Podział na prawo publiczne i prywatne nie ma zatem w ówczesnych stosunkach uzasadnienia. Posługujemy się nim jedynie ze względów tradycyjnych. Podkreślmy przy tym kolosalną zmianę, jaka zaszła $w$ dobie nowożytnej w zapatrywaniu na prawo prywatne. Stało się ono przedmiotem żywego zainteresowania państwa. Jego kodyfikacje są dziełem państwowych organów, władzy ustawodawczej. W istocie więc jest to dzisiaj również dzial prawa publicznego, tradycyjnie nazywany dalej prawem prywatnym. Tymczasem $w$ średniowieczu należało ono rzeczywiście do sfery działalności prywatnej. Panujący nie mieszał się do niego. Do tych spostrzeżeń odwolamy się niżej, przechodząc do zagadnienia recepcji prawa niemieckiego na wsi polskiej.

1.3. Zauważmy jeszcze, że $\mathrm{w}$ okresie, którym się zajmujemy, ta consuetudo miała charakter osobisty. Obowiązywała zasada osobowości praw, Personalitätsprinzip. Każda grupa ludności rządziła się swoim narodowym prawem.

1.4. Przypomnienie tego jest ważne ze względu na stosunki etniczne. Zapytajmy, kto średniowiecznej Polsce dostarczał kontyngentu osadników. Wiemy, że $\mathrm{w}$ ówczesnym osadnictwie zasadniczą rolę odgrywali koloniści dwóch narodowości, niemieckiej i polskiej. Inne, Wallonowie, Flamandzi, Fryzowie, pojawiają. się tylko sporadycznie; możemy ich więc $w$ swych rozważaniach pominąć.

1.5. Nie posiadamy żadnych danych statystycznych, które pozwoliłyby na określenie ówczesnego stanu zaludnienia Polski. Zapewne wahało się ono

1 J. R af acz, Dawny proces polski, Warszawa 1925, s. III; W. Hejnosz, Przedmowa do dziela Oswalda B a lzer a, Przewód sqdowy w zarysie (wyklad uniwersytecki), Lwow 1935, s. V; K. Sójka-Zielińska, Historia prawa, Warszawa 1981, s. 19.

${ }^{2}$ Inny to sens niż ten, który wystẹpuje w przywileju austriackim z 1187 r., Urkunden und erzählende Quellen zur deutschen Ostsiedlung im Mittelalter, hrsg. v. H. Helbig i L. Weinrich, T. 2, 1970, Nr. 124; tu chodzi o władzę sądową, przekazaną klasztorowi. 
około 1 miliona $^{3}$. Nie możemy też nic pewnego powiedzieć o tym, jaki procent ludności zamieszkiwal wieś, jaki - miasto. Wiadomo, że dominowali wieśniacy i według szacunków stanowili co najmniej $95 \%$ mieszkańców ${ }^{4}$. Zajmując się chłopskim prawem, omawiamy życie prawne całego niemal społeczeństwa.

Wieś i miasto różnią się znacznie poziomem cywilizacyjnym, pozostającym w związku z narodowością mieszkańców. W miastach odgrywające $\mathrm{w}$ życiu gospodarczym i społecznym rolę decydującą sfery górne (i chyba tylko one) są niemieckie. Przynależni do nich rządzą się, zgodnie $z$ powołaną zasadą osobowości praw, normami niemieckimi.

1.6. Podstawę prawa miejskiego stanowily dokumenty lokacyjne. Ale wcześnie szukały miasta polskie pouczeń bezpośrednio w Magdeburgu (nieraz pośrednio przez Środę Śląską lub Chelmno albo, rzadziej, w Lubece). Podstawę prawa magdeburskiego stanowiło przetłumaczone na łacinę we Wroclawiu w drugiej polowie 13. w. Zwierciadło Saskie. Tak więc w miastach polskich prawo sqdowe, prywatne, karne $i$ proces mialy glówna podstawe $w$ źródlach recypowanych ${ }^{5}$. W przedstawianym studium pomijamy w ogóle zagadnienia miejskie, ograniczając się do stosunków panujących na wsi.

1.7. Również tam w akcji kolonizacyjnej uczestniczyli i Niemcy i Polacy. Ale w jakim stosunku? Niemiecki Drang nach Osten toczył się przez siedem $\mathrm{z}$ górą stuleci (od 13. do 19. wieku). To zjawisko dobrze znane. W tym długim okresie niemało chlopów niemieckich powędrowało w celach osadniczych na wschód. Wiemy, że proces ten wymagał odpowiednich i to niemałych kapitałów. Każde pokolenie przyczyniało się do osadnictwa w miare swych zasobów finansowych. Wiemy też, z jakimi trudnościami borykała się hakata, korzystająca $\mathrm{z}$ krociowych funduszów udzielanych przez zainteresowany politycznie, a przy tym tak zasobny gospodarczo organizm, jakim było w końcu 19. i na początku bieżacego stulecia cesarstwo niemieckie. Tymczasem rezultat owej akcji kolonizacyjnej (i równocześnie germanizacyjnej) okazał się dość mierny, zdecydowanie niewspółmierny do finansowego wysiłku6 ${ }^{6}$.

${ }^{3}$ I. Gieysztor owa, Ludność, [w:] Encyklopedia historii gospodarczej Polski, t. 1, Warszawa 1981, s. 430. Por. tejże autorki, Wstęp do demografii staropolskiej, Warszawa 1976, ilustracje na s. 32; tamże wyrażenie niewiary w ustalenia ludnościowe w epoce prestatystycznej.

${ }^{4} \mathrm{G}$ i e y s z t o r owa, Ludnośc, s. 438.

${ }^{5} \mathrm{~S}$. Kutrzeba, Historia źródel dawnego prawa polskiego, t. 2, Kraków 1926, s. 201.

- Zdajemy sobie sprawę $z$ tego, że porównujemy ze sobą zjawiska $w$ istocie niewspólmierne. Działalność hakaty przypadła na okres, w którym Drang nach Osten ustępował już nieoczekiwanie a zdecydowanie odwrotnemu zjawisku, tzw. Ostflucht! 
1.8. Ale wróćmy do średniowiecza. Napływ ludności niemieckiej to rzecz niewątpliwa. Ale w jakich rozmiarach? W literaturze niemieckiej, a po części i polskiej, utrzymywano długo, że było to zjawisko masowe, choć - przyznajmy - niektórzy ostrożni a bezstronni badacze zajmowali stanowisko znacznie powściągliwsze ${ }^{7}$. Ale pogląd o ogromnym napływie kolonistów niemieckich bywa powielany nadal. Jego zwolennikiem zdecydowanym jest J. Menzel. Die maßenhafte Kolonisation (chodzi temu uczonemu o Śląsk trzynastowieczny) jest dla niego faktem niewątpliwym. Nie jesteśmy skłonni pójść za tym zdaniem. Nowa niemiecka migratio gentium wydaje się mało prawdopodobna. A już $\mathrm{z}$ pewnością nie dochodziło do niej przy przenoszeniu na prawo niemieckie osad od dawna istniejących, a tym samym zamieszkanych przez tubylców-Polaków. Obawiamy się, że uzasadnienie kwestionowanej tezy (poza patriotyzmem niemieckich autorów) stanowi przed stu laty głoszone blędne zapatrywanie znakomitych skądinąd historyków Śląska - G. A. Stenzla oraz A. Meitzena, którzy za każdą wzmianką o ius Teutonicum widzieli osiedlanie się niemieckich chłopów. Ostatni uczony naliczył tych przybyszów na Śląsk do... 180000 ! Nieporozumienie sprostowano dawno, a limine odrzucając podstawę rozumowania, ale stara konkluzja o maßenhafte Kolonisation żyje wśród historyków nadal ${ }^{8}$. Zdecydowane protesty $\mathrm{K}$. Tymienieckiego ${ }^{9}$ pozostaly bez echa.

1.9. Zgodzimy się z tym, że napływowa ludność narodowości niemieckiej - już bez względu na jej liczbę - posługiwała się w nowej ojczyźnie tym samym prawem zwyczajowym, według którego żyła dotąd u siebie, w Niemczech, a więc prawem niemieckim. To wydaje się oczywiste. Było to bowiem jej prawo rodzime, innego nie znała w ogóle. Przyniosła je z sobą do naszego kraju, gdzie je uszanowano zgodnie $z$ Personalitätsprinzip. To jedynie $z$ tą zasadą należy je wiązać ${ }^{10}$. Fakt osadnictwa iure Teutonico nie ma tu nic do rzeczy. We

${ }^{7}$ Por. H. F. Schmid, Die Siedlungen deutscher Kolonisten stellen, trotzdem je auch ihr Zahl gerade in dieser Zeit (w czasach Kazimierza Wielkiego i Andegawenów) nicht gering ist, nur einen kleinen Bruchteil der Gesamtzahl der nach deutschem Recht lebenden Orte dar (Krzem., s. $33^{*}$ ).

${ }^{8}$ Podzielają go współcześnie niektórzy historycy polscy. A. Gi eys ztor (Les chartes de franchises urbaines et rurales en Pologne au XIIIe siècle, [W:] Les libertés urbaines et rurales, Bruxelles 1968, s. 107) formułuje swój pogląd tak: L'afflux de la population allemande, attesíc dans les campagnes de la Basse Silésie dès 1175 dans la familia d'un couvent cistercien (ibidem. s. 122), zaakcentowanie: l'imigration étrangère, particulièrement forte en Silésie! Tak tè jeszczc A. Körmendy, Ksztaltowanie sie pojecia prawa niemieckiego (ius Teutonicum) w Europie śodkowo-wschodniej $w$ XIII-XIV w., PH 1984, t. 75, s. 484. Za opinią o znacznym naptywie niemieckich kolonistów-rolników opowiada się ostatnio w swej syntezie również $N$. D a vi es, Boże igrzysko. Historia Polski, t. 1, Kraków 1989, s. 84.

${ }^{9} \mathrm{~K}$. T y mi eni ecki, Kolonizacja a germanizacja Ślqska $w$ wiekach średnich, Katowice 1937, s. $15-16$.

10 Tak - sądzimy - rozumieć należy wypowiedź J. J. M enzla - materialne prawo niemieckie osadnicy niemieccy przynosili $z$ sob̨̨ (Menzel, s. 287). 
wsiach przez nich zamieszkanych ławnicy byli niemieckiej narodowości, znali zatem tylko prawo niemieckie, a nie znali polskiego. Tak było w Krzemienicy, gdzie cała ludność jest obcego, niemieckiego pochodzenia. W takim razie przy osadzaniu się obcokrajowców, zachowujących swoje consuetudines, $\mathrm{m}$. in. także rodzime prawo, zagadnienie recepcji nie wchodzi w ogóle w rachubę; mówienie o niej w takim wypadku to wręcz absurd. Tak jak i inne mniejszości narodowe mieszkające $w$ Polsce - Żydzi ${ }^{11}$, Ormianie itp., również swego prawa, prawa niemieckiego, nie recypowali Niemcy. Oni je z sobą przynosili. W ich prawnym usytuowaniu nie ma zatem nic szczególnego.

Dla niemieckich przybyszów jedyna we wskazanej sytuacji moźliwość recepcji - to przejęcie wraz z polonizacją (następowała ona szybko, w ciągu 2-3 pokoleń) polskiego systemu prawnego. $Z$ tą ewentualnością nie liczy się tymczasem nikt!

1.10. W średniowieczu, ze względu na wysokie koszty osadnictwa ludnością obcą, wcześnie zwrócono się do chłopa-tubylcy, a zatem polskiego! On był na miejscu; o ileż tańsza inwestycja kolonizacyjna! Oni też stanowią główny element osadniczy ${ }^{12}$. A zważmy na to, że najczęściej przy melioracio terre o nowym osadnictwie nie było w ogóle mowy; przenoszono na prawo niemieckie osady już istniejące, a więc zasiedlone od wieków przez tubylców-Polaków. Wówczas zmianie ulegały niewątpliwie stosunki własnościowe ${ }^{13}$. Czyżby równocześnie ci polscy chłopi, stając się właścicielami podrzędnymi,

${ }^{11}$ Że oni nie podlegali niemieckiemu prawu, stwierdza wyraźnie spis prawa chelmińskiego D I 35: Item omnes Iudei et scismatici vel etiam pagani in civitatibus seu oppidis et in quibuscunque locis inhabitant, nullo iure Theutonicali uti possunt, nec sint tales in ius civile recipiendi pro eo, quia ipsi suum ius speciale et iudicem habent. Et cum aliquis christianus ipsos ad ius suum civile citabit, tales cum negaverint, super crucem non debent admitti iurare, quia ipsi sunt in signo sancte Crucis risores et detractores signo Dei; por. Z. R y m as zewsk $\mathrm{i}$, Nieznany spis prawa chelmińskiego z przelomu 14./15. wieku. Łódź 1993, s. 134. Analogiczne, choć w tym wypadku krótkotrwałe tendencje w stosunku do Rusinów, por. A. J a ne czek, Exceptis schismaticis. Upośledzenie Rusinów w przywilejach prawa niemieckiego Wladyslawa Jagielly, PH 1984, t. 75, s. 527-541. Natomiast we Lwowie nadane w r. 1356 ius Teutonicum objełło wszystkich mieszkańców, a więc Ormian, Rusinów, Saracenów i Żydów; K. K a m i ńsk a, Lokacje miast na prawie magdeburskim na ziemiach polskich do $1370 \mathrm{r}$., Toruń 1990, s. 163.

${ }^{12} \mathrm{Z}$. Wojci e ch owski podkreśla, że kolonizacja wyzyskiwała liczną u nas, także i na Śląsku, warstwę wolnych gości, którzy byli bezrolni, a więc stanowili znakomity materiał osadniczy (Uströj polityczny Ślaska, 1. W okresie do 1327/9 r., [w:] Historia Ślqska od najdawniejszych czasów do r. 1400, t. 1, s. 680). B. Zi e nt a r a ostatnio wypowiada pogląd, że liczba niewolnych $\mathrm{w}$ okresie przedkolonizacyjnym nie przekraczała $10 \%$ ludności (Die Bauern in mittelalterlichen Polen, APH, Bd. 57, s. 16).

13 Por. nasz artykul pt. Ius Teutonicum. Sredniowieczna reforma rolna $w$ Polsce, [w:] Zagadnienia prawa konstytucyjnego. Ksiega pamiqtkowa ku czci profesora Tadeusza Szymczaka, Lódź 1994, s. 237-241. 
recypowali prawo niemieckie? ${ }^{14}$ Oto zagadnienie, które zamierzamy w przedstawianym tu artykule rozpatrzeć.

1.11. Trudno liczyć się z wpływem zwyczajowego prawa niemieckich kolonistów na prawo polskich chłopów. To zjawisko należałoby brać pod uwage wówczas tylko, gdyby Niemcy przeważali liczbowo, gdyby polska ludność $\mathrm{w}$ ich otoczeniu ulegała germanizacji. Ale to raczej koloniści niemieccy szybko się polonizowali. A w związku z tym procesem należałoby się liczyć $\mathrm{z}$ przyswajaniem przez nich polskiego prawa.

1.12. Wszakże od razu nasuwa się poważny szkopuł: dlaczego wobec polskich osadników nie znalazła zastosowania wspomniana wyżej zasada osobowości praw? $\mathrm{Z}$ jakiej racji ich upośledzenie? Dlaczego oni mieli rezygnować $\mathrm{z}$ rodzimego prawa, które znali, i recypować obce, niemieckie, którego ewidentnie znać nie mogli? Tym bardziej, gdy w zdecydowanej większości wypadków przechodzili jedynie na nowe warunki osadnicze (własność podzielona), choć pozostawali dalej na dotychczasowych gospodarstwach. W istocie $\mathrm{z}$ czasowych, a więc każdej chwili usuwalnych osadników-dzierżawców, stawali się w ramach ius Teutonicum właścicielami (podrzędnymi) zagród, na których dotąd siedzieli ${ }^{15}$. Mieliby $\mathrm{z}$ tej racji przejmować równocześnie niemieckie prawo sądowe?

Czemu w takim razie przypisać uprzywilejowanie kolonistów niemieckich? Im - powtarzamy - gwarantuje się ich dawne, niemieckie zwyczaje. Tymczasem polskiej ludności, w tej samej sytuacji, tego samego się odmawia! Gdzie tu znaleźć uzasadnienie takiego postępowania? $\mathrm{Z}$ jakiej racji? Po co? Cui bono?

1.13. Pamiętając o wskazanym rozróżnieniu prawa niemieckiego - raz jako melioracio terre iuxta modalum Teutonicum, to znów jako ius Teutonicum iudiciarium - przechodzimy od rozpatrzonej niedawno kwestii przeprowadzanej $\mathrm{w}$ interesie powszechnym reformy rolnej ${ }^{16}$, do tak istotnego dla prawnika zagadnienia recepcji niemieckich norm prawnych na wsi polskiej. Czy dokonała się ona rzeczywiście wraz $\mathrm{z}$ akcją kolonizacyjną, $\mathrm{z}$ ową locatio iure Teutonico i była jej naturalnym a zrozumiałym następstwem? Czy więc - powtórzmy - iuris Teutonici collatio ${ }^{17}$ to nie tylko wprowadzenie własności podzielonej, ale również przejęcie przez osadników polskich niemieckiego ius iudiciarium. Przyjrzyjmy się zagadnieniu bliżej.

\footnotetext{
${ }^{14}$ Ostatnio nie ma wątpliwości co do tego J. Wyrozumski, Czy bylo polskie prawo osadnicze?, [w:] Ojczyzna bliższa i dalsza, Kraków 1993, s. 305-310.

15 Pogorszenia się swego polożenia w przyszlości, w okresie wtórnego poddaństwa, przewidzieć oczywiście nie mogli.

${ }^{16}$ Quod ius Theutonicum Sredense sive Nouifori nobis [królowi] et regnicolis nostris multum utilitatis affert. KDWP 6, nr 198a, r. 1362; por. artykuł powołany wyżej w przyp. 13.

${ }^{17}$ Menzel, nr 128, r. 1294.
} 
2.1. Zastanówmy się nad tym, co poczytuje się za recepcję. Znana w Niemczech Aufnahme des fremden Rechts znaczy uznanie prawa rzymskiego za prawo obowiązujące $w$ tym kraju, choć $w$ charakterze prawa posiłkowego ${ }^{18}$. Dokonała się ona odgórnie, przez zawodowych prawników, którzy w szkołach i uniwersytetach zaznajomili się $\mathrm{z}$ obcym prawem. Geneza recepcji była zatem uczona. Innego sposobu jej przeprowadzenia nie widzimy. Tym bardziej nie wyobrażamy sobie tego, by mogli jej dokonać ludzie prości, którzy nie zdobyli nigdy wykształcenia prawniczego i nie spotkali się $\mathrm{z}$ obcym prawem $w$ praktyce sądowej. $Z$ takim rozumieniem recepcji - czy można sobie wyobrazić inne? - powróćmy na trzynastowieczną wieś polską.

2.2. Stwierdźmy od razu, że oba zjawiska - reforma rolna i recepcja obcego ustroju sądowego i prawa - stanowią zagadnienia odrębne, nie pozostające z sobą w związku koniecznym: jedno mogło nastąpić bez drugiego. Po prostu, przeprowadza się reformę rolną iure Teutonico, to znaczy osadza się chłopów-Polaków w charakterze właścicieli podrzędnych, a równocześnie nie dokonuje się żadnej zmiany prawa sądowego, którym się ci poddani mieli rządzić i sądzić. Latwo sobie wyobrazić sytuację, w której życie polskich chłopów-kolonistów w nowych warunkach osadniczych (własność podzielona) toczy się dalej, według starych zwyczajów, dziedziczonych od pokoleń. Ich consuetudines nie musiały i chyba nie mogły ulec zmianie $\mathrm{z}$ dnia na dzień. Naturalne wydaje się pozostanie przy starych normach. Szukajmy argumentów dalszych.

2.3. Przypomnijmy fakt, że prawo niemieckie poprzedzal immunitet. Znane nam, przezeń wprowadzane istotne zmiany, w świetle zachowanych dokumentów nie dotyczyły $w$ żadnym wypadku prawa sądowego. Nim się nie zajmowały przywileje immunitetowe w ogóle, poza jednym istotnym zresztą szczególem: w miejsce sądownictwa książęcego wprowadzały sądownictwo prywatne, pańskie. Sądząc zatem z ich milczenia, nabieramy przekonania - wedhug naszego mniemania nie ma $\mathrm{w}$ tym żadnego ryzyka - że $\mathrm{w}$ immunizowanych wsiach obowiązywało nadal zwyczajowe prawo prywatne polskie. W tym względzie nie zmieniało się nic. A czy nie tak samo przedstawia się owo zagadnienie $\mathrm{w}$ wypadkach lokacyj na prawie niemieckim?

3.1. Najpierw zadajemy sobie pytanie, czy społeczeństwo nasze było do recepcji prawa niemieckiego przygotowane? Czy mogło wśród rdzennie polskiej ludności do niej w ogóle dojść? Zacznijmy rozważania od postawy ludności chłopskiej. A tu dostrzegamy od razu następującą trudność.

${ }^{18}$ Por. R. Hübner, H. C o n r a d i in. Z dumą podkreślają uczeni francuscy, że u nich do recepcji rzymskiego prawa nigdy nie doszło. 
Latwo powiedzieć: nadajemy wam - kolonistom - (sądowe) prawo niemieckie. Ale jak tę deklarację wprowadzić w czyn? Wiadomo: consuetudo - altera natura; nie łatwo ja zmienić! Skłonniśmy nawet mówić o konserwatyzmie chłopa w ogóle, a więc także prawniczym. A tymczasem zmiana jego prawa sądowego miałaby się dokonać za jednym zamachem? Czyżby następowała już $w$ momencie osadzenia się polskiego gościa iuxta modalum Teutonicum?

3.2. Co więcej, jeśli sądy wiejskie, obsadzone przez lawników Polaków, miały stosować rzeczywiście prawo niemieckie, to uzasadnione wydaje się pytanie, gdzie się $\mathrm{z}$ nim zapoznały. W społeczeństwie średniowiecznym analfabetyzm jest powszechny. Czytać i pisać chłopi z pewnością nie umieli $^{19}$. Do spisów prawa więc zaglądać nie mogli. Nawet ci, którzy wchodzili w skład lawy wiejskiej. To przecież - pamiętajmy - nie juryści, lecz prości chłopi! ${ }^{20}$

3.3. Co więcej, dostrzegamy trudność dodatkową: zbiory prawne zredagowane były w językach obcych - łacińskim lub niemieckim. $Z$ ich znajomością było u wiejskich ławników polskich z pewnością źle - poza językiem ojczystym innego nie znali.

3.4. A przy tym zapytujemy: jak wśród rdzennie polskiej ludności do recepcji obcego prawa mogło w ogóle dojść? Jeśli sądy wiejskie, obsadzone przez lawników Polaków, miały stosować prawo niemieckie, to uzasadnione wydaje się pytanie, gdzie się $\mathrm{z}$ nim zapoznały. $\mathrm{Z}$ góry wykluczamy jedną z teoretycznych możliwości - nikt tego prawa ich nie uczyl. Teza ta - sądzimy - nie wymaga dowodu. Ono było zresztą zwyczajowe! A w takim razie osadnicy polscy nie tylko prawa niemieckiego nie znali, ale nawet zapoznać się z nim nijak nie mogli! Zatem członkom sądu ławniczego we wsiach polskich prawo niemieckie było kompletnie obce. Przedstawione wyniki osiągnęliśmy rozpatrując kompetencję sądów wiejskich, złożonych z miejscowych chłopów. Ale może inni uczestnicy akcji lokacyjnej znali prawo niemieckie i mogli je propagować?

3.5. Zwyczajowego, obcego prawa nie znali nie tylko koloniści polscy. W tej samej sytuacji znajdowali się również inni polscy uczestnicy lokacyjnej akcji. Nie mówimy już o władcy; to oczywiście nie dla niego problem (por. ust. $4.2)$.

19 Jeszcze w polowie $16 \mathrm{w}$. niemieccy mieszkańcy Czarnej nie umieli ani czytać, ani pisać (Krzem., s. $48^{*}$, przyp. 2).

${ }^{20}$ Przypomnijmy, że nawet $w$ mieście, w Poznaniu, w sądach zasiadali nie prawnicy, lecz rzemieślnicy, a więc również osoby bez jakiejkolwiek formacji prawniczej (W. Maisel, Sqdownictwo miasta Poznania do końca XVI w., Poznań 1961, s. 312-313). 
3.6. Zważmy na następujący wypadek, który zmusza do refleksji. Nie wahalibyśmy się ze stawieniem tezy, wydawałoby się oczywistej: chłopi-Niemcy z sołtysem-Niemcem rządzą się zawsze prawem niemieckim. Tymczasem z 1443 r. znamy następujący zapis: Item Mathias Hohewser coram iudicio bannito interrogavit scultetum, utrum haberet ius Dewtunicale. Scultetus dixit: „,habeo ius Dewtunicale" (Kroś. nr 1807). Zatem dla wspólczesnych nawet co do soltysa, najbardziej prominentnego, zdawaloby się, uczestnika kolonizacji na niemieckim prawie, a przy tym jeszcze przełożonego osady zasiedlonej przez Niemców (!), nie ma pewności co do tego, czy rządzi się prawem niemieckim, czy... polskim!

Domysł, na pozór dla historyka oczywisty, bynajmniej takim nie jest ${ }^{21}$. Rzeczywistość po prostu mogla być inna! - Jakaż to przestroga przed wyłącznie teoretycznymi rozważaniami. Bez oparcia źródłowego historykowi twierdzeń żadnych wygłaszać nie wolno!

3.7. Ostatecznie, ale naprawdę już ostatecznie, można by o znajomość prawa niemieckiego podejrzewać skrybę. To jedyna osoba, która w sądzie wiejskim nie była analfabetą. Wszakże i tu przeprowadzilibyśmy rozróżnienie: pisarz niemiecki czy polski. Pierwszego znajdziemy na wsi zaludnionej przez Niemców; on niewątpliwie prawo niemieckie znal. Natomiast nie zetknął się $\mathrm{z}$ nim polski skryba chyba nigdy. A zresztą do kompletu sędziowskiego nie należał. Nie sądzimy zaś, by cieszył się autorytetem, umożliwiającym narzucenie swej opinii polskiemu plebejskiemu kompletowi sędziowskiemu.

3.8. A co $\mathrm{z}$ lokatorami-sołtysami? Znali oni prawo niemieckie, gdy byli Niemcami. Wszakże w późniejszej dobie kolonizacyjnej przeprowadzenia osadnictwa podejmowali się już z reguły Polacy, bogaci mieszczanie, niekiedy zamożniejsi chłopi, a coraz częściej nobiles ( $\mathrm{z}$ czasem - jak to wykazał w swych pracach Ludwik Łysiak - ci ostatni opanowali wójtostwa i sołectwa w większości). Gdy więc zasadźca-Niemiec rzadkim stał się wypadkiem, przy sołtysie-Polaku w rachubę wchodziła u niego tylko znajomość zwyczajowego prawa polskiego. Ignorancja jego z zakresu prawa niemieckiego w późniejszym okresie kolonizacyjnym nie ulega wątpliwości.

3.9. Także i główny motor akcji kolonizacyjnej - właściciel ziemski mówił o sobie iura Teutonica sunt nobis penitus incognita. Rycerz polski z pewnością nie zapoznał się $\mathrm{z}$ nimi nigdy. On także był analfabetą. Wykształcenie posiadali jedynie duchowni. Zważmy wszakże, że biskupami w Polsce, nie

${ }^{21}$ Inna rzecz, że w postawionym soltysowi pytaniu o prawo, któremu podlega, kryła się prawdopodobnie nie kwestia stosowanego prawa materialnego, lecz osobnego trybunału, leńskiego sądu, właściwego stanowi sołtysiemu! 
wyłączając Śląska ${ }^{22}$, byli w 13. w. wyłącznie Polacy. Czyżby oni studiowali kiedykolwiek prawo niemieckie? Tylko cystersom proweniencji niemieckiej23, bo już nie francuskiej, nie odmówimy znajomości niemieckiego prawa sądowego. W sumie to niewielu znawców obcego prawa wśód wielkich właścicieli ziemskich.

3.10. Rezultat zatem zdumiewający. Okazuje się, że na wsi polskiej mało kto $\mathrm{z}$ uczestników osadnictwa mógł znać zwyczajowe prawo niemieckie. Obce było ono panom, wyjąwszy cystersów niemieckich. To samo powiemy o zasadźcy: znał je, o ile byl Niemcem, co zdarzało się coraz rzadziej. Znali je koloniści, o ile byli Niemcami. Wysnuwamy zatem konkluzję generalną: niemieckie prawo materialne $i$ formalne wchodziło $w$ rachubę w tych jedynie wsiach, w których kolonistami byli Niemcy. I tylko tam! Przy polskich osadnikach obce prawo nie mogło znaleźć zastosowania $\mathrm{z}$ prostego powodu: nikt $\mathrm{z}$ lawników go nie znal! $\mathrm{W}$ praktyce przesądzała zatem narodowość osadników: niemiecki chłop znał jedynie niemieckie prawo, polski - wyłącznie polskie. Czy mogło być inaczej? Prawa niemieckiego na polskiej wsi nie znal nikt. Natomiast wioski $z$ kolonistami niemieckimi poczytaliśmy za zjawisko nie częste. Zresztą w otoczeniu polskim - powtórzmy - obcy polonizowali się gwałtownie (por. ust. 1.9).

Odpowiedź dajemy w końcu zdecydowaną. Na wṣi polskiej od samego początku akcji kolonizacyjnej niemieckiego prawa sądowego nie znal nikt z Polaków: ani panujący, ani właściciel ziemski, rycerz czy duchowny, ani chłopi. Bo - powtórzmy pytanie - gdzie i kiedy mieliby się oni $z$ nim zetknąć i je sobie przyswoić? Prawo niemieckie znali tylko Niemcy. Wchodziliby więc $u$ nas w rachubę: zasadźca, przyszły soltys, o ile był Niemcem - co było zjawiskiem coraz rzadszym, oraz cystersi i osadnicy niemieccy. Nie bez racji stwierdzały statuty Kazimierza Wielkiego: wsie polskie lokowane na prawie niemieckim iure Theutonico obmisso secundum ius Polonicum se regunt in quibusdam! ${ }^{24}$

${ }^{22}$ R. K ötzsch k e, W. E bert, Geschichte der ostdeutschen Kolonisation, Leipzig 1937, s. 81.

${ }^{23}$ Zwróćmy uwage na to, $z$ jaka niechẹcią odnosił się do niemieckich kolonistow miemieck opat henrykowski. Polski rycerz osadzal ich u siebie mnichom ,na ziośc": sed quia idem Michael (sąsiad klasztoru) studebat sepius claustrum nostrun gravare, locavit suam hereditaten: Thetonicis, Ks. Henr., s. 273. Nie wiemy, na czym polegała ich uciążliwość dla klasztoru.

${ }^{24}$ L. Ly siak, Ius supremum Maydeburgense castri Cracoviensis 1356-1794, Frankrtw th Main 1990, s. 15: ...in den von der fortschreitenden Ostkolonisation erfaßten Gebieten, wo dus neue Recht schlecht bekannt war und daher vielfach ais ius incognitum betrachtet wurde; a dale; s. 18: die immer noch schwache Kenntnis des deutschen Rechts, besonders in dörflichieit Verhältnissen, die sogar eine Abwendung von diesem Recht und Rückkehr zum polnischen Recht zur Folge haben konnte; por. też ibidem, s. 48. 
4.1. Zastanówmy się $\mathrm{z}$ kolei nad tym, kto mógłby być zainteresowany $\mathrm{w}$ recepcji niemieckiego prawa sądowego $\mathrm{w}$ osadzanej iure Teutonico wsi - panujący czy Kościól, a może sołtys lub chłop czy sam pan. Ostatecznie nic nie dzieje się bez przyczyny!

4.2. Panujący: skłonniśmy sądzić, że ten, przekazawszy w nadaniu immunitetowym właścicielowi ziemskiemu poważną część uprawnień władczych, m. in. wymiar sprawiedliwości, okazywał całkowite désintéressement wszystkiemu, co działo się dalej w dobrach immunisty ${ }^{25}$. Obojętny mu zatem był zarówno ustrój sądu patrymonialnego, jak i prawo, którym mieli się teraz koloniści rządzić. Do jednego tylko od razu zglaszał pretensje - do świadczeń nadzwyczajnych, a one nie pozostawały $w$ żadnym związku $\mathrm{z}$ prawem sądowym.

4.3. Kościól: niewątpliwie byl zainteresowany powodzeniem kolonizacji, jak każdy właściciel ziemski. Prawo niemieckie nadawano duchownym, cum meliorata condicione terrarum meliorari debeat condicio ecclesiarum (SUb 4, $\mathrm{nr}$ 157), ad fructuose melioracionis augmenta reduci, [...] ad usus redigi maliores (Menzel, $\mathrm{nr}$ 98, r. 1284), quia melioracionem ex hoc condicionis ecclesie nostre [...] credimus provenire (Menzel, nr 134, r. 1296). Chodzilo przede wszystkim o zwiększenie rentowności włości, a ponadto o zagęszczenie zaludnienia (akcentuje to H. F. Schmid), co mnożyło świadczenia dziesięcinne oraz inne opłaty kościelne, a nie o wprowadzenie niemieckiego sądu i o recepcje niemieckich norm prawnych. Kościół czerpać będzie korzyści z osadnika, opierając się dalej na przepisach kanonów, nie na prawie niemieckim. Zatem obu wspomnianym czynnikom - i panującemu, i kościołowi - obojętne bylo prawo sądowe, zarówno ustrój sądu, jak i prawo materialne czy procedura stosowana $w$ trybunale wiejskim.

4.4. Najwyraźniej uwidacznia się korzystna pozycja soltysa. On był niewątpliwie zainteresowany w zaprowadzeniu sądu ławniczego, albowiem należała mu się za przewodniczenie temu trybunałowi (dlatego dokumenty nazywają go nieraz scoltetus et iudex ${ }^{20}$ 1/3 kar sądowych ${ }^{27}$. Wysokość jego dochodów zależała

${ }^{25}$ Praktycznie - jak sądzimy - nie odgrywało żadnej roli zastrzeżenie dla księcia kompetencji w wypadku iusticia denegata.

26 Dokumenty klasztoru PP. Norbertanek w Imbramowicach, wyd. Z. Kozłowska-Budkowa, Kraków 1948, nr 8, r. 1275. Sporadycznie zwie się on w księgach lawniczych generałem (generalis) (T. $\mathrm{nr} \mathrm{4,6,8).}$

${ }^{27} \mathrm{~W}$ okresie wolnizny soltys prawdopodobnie pobierał kary sądowe w całości. W konkretnym wypadku klasztor postanawia: ...item durante libertate de iudicio nichil ad nos pertinebit, (Imbramowice, nr 8, r. 1275). Sprawa o tyle skomplikowana, że w tym samym akcie przewiduje się dwa rodzaje wolnizny; jeden - dhuższy, szesnastoletni, ad colendum et extirpandum; drugi - krótszy, sześcioletni - widocznie dla gruntów już kiedyś uprawianych; praktycznie stworzyć to mogło dalsze komplikacje, w które nie chcemy już wchodzić. 
również od liczby i wagi spraw, które rozstrzygał. Czyżby również od stosowanego prawa, którym się będzie lawa kierować? Czy wówczas pobierano wyższe kary? Tu musimy powtórzyć argumentacje, którą poshużyliśmy się wyżej ${ }^{28}$.

4.5. Rozważmy sytuację, w jakiej znaleźli się najczynniejsi uczestnicy osadnictwa - koloniści. Pan, pragnąc ich sobie skaptować, obojętnie jakiej narodowości - niemieckiej czy polskiej - oddawał im na własność (podrzędną) nie tylko duży obszar gruntu - jeden lan, ale obiecywal dodatkowo, że na nowej siedzibie sądzić się będą sami! Zgadzal się tym samym na powstanie samorządnego trybunału, złożonego z soltysa jako przewodniczącego i z siedmiu ławników-chłopów. Daję wam - stwierdzal - sądownictwo równych (iudicium parium), złożone $\mathrm{z}$ was, samych plebejów! Taki skład zapewniał kolonistom jakąs gwarancję ochrony przed samowolą i nadmiernym wyzyskiem ze strony feudała.

Samorządne sądownictwo było dla nich dodatkową korzystną ofertą. $\mathrm{O}$ nim informują $\mathrm{z}$ reguły przywileje lokacyjne. Zdajemy sobie sprawę $\mathrm{z}$ tego, że to innowacja istotna, przedstawiająca niemały walor dla ludności wiejskiej. Sądownictwo parów mogło w poważnym stopniu ulatwić werbowanie osadników: dawało gwarancje sądzenia przez osoby równe stanem! Tu rola prawa niemieckiego byla chyba decydująca. Wprowadzenie iudicium parium przez ius Teutonicum skłonni bylibyśmy uznać za pewnik!

4.6. Pan: dla niego wprowadzenie sądu wiejskiego pociągało za sobą stratę $1 / 3$ kar sądowych, które odstępował soltysowi. Uszczerbek zatem niewątpliwy. Wszakże zgadzając się na stworzenie u siebie sądów lawniczych, przez ten krok bynajmniej nie zrzekał się wpływu na wymiar sprawiedliwości $w$ swych dobrach, skoro warował sobie nad nim kontrole przez uczestnictwo $w$ tzw. wiecach wielkich, iudicia magna, odbywanych trzy razy do roku $^{29}$. I to na koszt chłopów (in eorum procuratione). Co jednak istotne, sądownictwo patrymonialne utrzymywało się nadal. Nie lekceważmy sobie tego zastrzeżenia. Ono umożliwi panu interwencję $\mathrm{w}$ razie zagrożenia jego własnych interesów. Niewątpliwie już samo istnienie podobnej rezerwacji stanowi wystarczający dowód nadzorczych uprawnień wlaściciela nadrzędnego -- pana. Ono - w przyszłości - umożliwi mu calkowitą likwidację samorządności tego sądownictwa ${ }^{30}$, które $\mathrm{w}$ ten sposób pozostanie dalej pod ręka pańskq!

${ }^{28}$ Pomijamy tu kwestię podległości osobistej sołtysa „prawu niemieckiemu”, osobnym trybunałom leńskim, bo to inny problem.

${ }^{29}$ To ma wynikać w prawa średzkiego: Hoc etiam nostri iuris erit, quod ter in anno eorum iudiciis intererimus, vel aliquem mittemus a nostro latere, sicut consuetudo Novoforensis habet, Imbramowice, $\mathrm{nr}$ 8, r. 1275.

$30 \mathrm{O}$ niej w naszym artykule lus Teutonicum..., s. 226, gdzie wskazujemy na wyraźną zależność sądu ławniczego od opata lubińskiego. 
Czy mogła powetować panu strate $1 / 3$ kar sądowych recepcja materialnego prawa niemieckiego przez chłopów? Czy zwiekszała jakoś dochody immunisty? Czyżby uległy znacznemu podwyższeniu kary sądowe? Przecież o nich decydować miała odtąd plebejska lawa; jej życzliwe nastawienie wobec współmieszkańców nie podlega wątpliwościom; ona nie bẹdzie się srożyć wymierzaniem podsądnym arcysurowych kar pieniężnych. Nie widzimy więc również między omawianymi zjawiskami żadnej lączności.

4.7. Te wstępne konstatacje okażą się niezbędne przy dalszych rozważaniach nad przejęciem prawa niemieckiego na wsi polskiej. Przede wszystkim zwróćmy się do źródel. Jedynie one miarodajne. Co nam powiedzą? Przypomnijmy tu spostrzeżenie, dotyczące treści pojęcia ius iudiciarium (ust. 1.1), jak i nastẹpne, które poczyniliśmy odnośnie do braku rozróżnienia w średniowieczu prawa publicznego i prawa prywatnego (ust. 1.2).

B

5.1. Zacznijmy swój wywód od terminologii. Ona jest jedynym niemal pośrednikiem, łączącym historyków, a zwlaszcza historyków prawa, z mentalnością minionych pokoleń, również $\mathrm{z}$ ich myślą prawniczą ${ }^{31}$. Zastanówmy się nad tym, co znaczy dla źródel ius Teutonicum?

5.2. Regułą języka jest - wiadomo - wieloznaczność. Odniesiemy ją tym bardziej do średniowiecza, gdzie z jednoznacznością nigdy chyba nie mamy do czynienia ${ }^{32}$. Zapytajmy zatem, czy wspomnianemu wyrażeniu ius Teutonicum nie przypisywano równie wielorakiej treści?

5.3. Samo ius rozumiano na różne sposoby ${ }^{33}$. Niewątpliwie znaczyło to słowo prawo; do tego sensu przejdziemy dalej. Nie on jednak przyświecał pisarzom wiejskich ksiagg lawniczych, gdy notowali zwroty: dedit ius scabinorum (T. nr 222), posuit ius scabinale alias unum solidum (T. nr 366), albo super hoc posuerunt suum ius scabinorum (T. nr 353), lub posuit ius scabinale vel suum solidum (T. $\mathrm{nr}$ 354). W tych kontekstach ius znaczy tyle, co et posuit memoriale mentis (T. $\mathrm{nr}$ 365), albo solidavit suo solido (T. $\mathrm{nr} 515$ ), albo et ius scabinorum posuit, quod iudicium suscepit (T. nr 624), czy posuit suum ius scabinale vel testimoniale ( $\mathrm{T}$. $\mathrm{nr} 211,212)$, lub posuit ius solidorum (T. nr 312).

W języku niemieckim oddaje się ten sam zwrot tak: vnd off dy beschedwnge hot [...] iren scheppen scheling gelet (Krzem. nr 623), vnd off das bekenthnos vnd off dy freylosswnge hot [...] sss gelet (ibidem, $\mathrm{nr}$ 624), vnd off das

31 O znaczeniu badań terminologicznych. J. Matuszewski, Pulapki średniowiecznej laciny, CPH 1983, 35, z. 1, s. 1.

32 Ibidem, s. 8 i n.

${ }^{33}$ Pomijamy walor kuchenny wyrazu ius, polewka. 
geczewgnos hot [...] sss gelet (ibidem, $\mathrm{nr}$ 647), vnd dy rechtunge haben sy [...] sss gelet (ibidem, $\mathrm{nr} 663$ ), vnd dor obir hot [...] off dy macht sss gelet (ibidem, $\mathrm{nr}$ 666), vnd off dy vorheysswnge hot [...] iren ss gelet (ibidem, $\mathrm{nr} 677$ ), wnd off $d y$ voryowartunge habben sy $d y$ rechtwnge beleth (ibidem, $\mathrm{nr}$ 678), vnd off $d y$ rede hot [...] sss gelet (ibidem, $\mathrm{nr} 684$ ), vnd off das bekenthnos vnd off $d y$ freylesswnge hot [...] sss gelet (ibidem, $\mathrm{nr}$ 688), vnd off $d y$ globde hot [...] iren sss gelet (ibidem, $\mathrm{nr} 715$ ).

$\mathrm{W}$ protokolach redagowanych po polsku czytamy: vnyesl szebye $w$ regestr szwym groszem (T. nr 878); grosem swoyem zalozil (Komb. $\mathrm{nr} 326,341$ ) lub oblozil (ibidem, nr 337-338), prawu w pamięthne groszem oblozyl (ibidem, $\mathrm{nr}$ 365-367), albo prawu groszem w pamięcz oblozyl (ibidem, $\mathrm{nr}$ 368-369).

Wszystkie przytoczone zwroty, lacińskie, niemieckie i polskie, znaczą tyle, że strona procesowa uiściła sądowi ławniczemu należną opłatę, in hoc ipse posuit suum sepslingum (T. $\mathrm{nr} 60$ ), in hoc posuit testimoniale alias sepszelinnek ( $\mathrm{T}$. $\mathrm{nr}$ 174), zwaną memoriale, pamiętne, a po niemiecku schöffen-schilling. I tylko to. $\mathrm{O}$ żadnym prawie nie ma $\mathrm{w}$ przytoczonych zwrotach w ogóle mowy!

5.4. Ius to również świadczenie wsi na rzecz pana; jest więc ono synonimem solutio: ut sepedicta villa eidem iuri stet et solutioni (SUb $1 \mathrm{nr} 210$, r. 1221).

5.5. Ale ius to także sąd wiejski złożony $\mathrm{z}$ soltysa i ławy: ipsi totum ius decrevit (T. $\mathrm{nr}$ 757); qui supradicti fuerunt in iure interogati (T. $\mathrm{nr} 575)$; et fuit interogatus a iure (T. $\mathrm{nr} 870)$; ius recognovit (T. $\mathrm{nr} 895)$; fuit interogatus a iure (T. $\mathrm{nr}$ 925). To skrót wypowiedzi ius banitum: ius banitum sibi decrevit (T. $\mathrm{nr}$ 194) ius banitum, hoc est viceadvocatus cum septem iuratis (T. nr 200); protestavit suo solido iuri banito (T. nr 664). To zatem to samo, co iudicium banitum (T. $\mathrm{nr}$ 791).

$\mathrm{Na}$ polskie zostanie przethumaczone owo ius dosłownie przez prawo: przed (zagayonym) pravem (T. nr 2666; por. też ostatnie cytaty poprzedniego ustępu). Ściślej wypowiadają się w tym samym kontekście zwroty niemieckie: vor vnser gehegete banc (Krzem. $\mathrm{nr} 4 \mathrm{i}$ in.), a zatem przed wiejską ławą gajoną.

5.6. Czasem znów pod wyrazem ius sama lawa przeciwstawiona zostaje sołtysowi: peciit advocatum cum ipsius iure (T. $\mathrm{nr}$ 895).

5.7. Równocześnie ius $w$ tych samych księgach to wyższy sąd prawa niemieckiego, ad supremum ius ad Croszno (T. nr 864). Także sąd najwyższy, krakowski oberhof, (Maszk. nr 523, r. 1482) extunc prefata nobilis uxor sua legitima Katherina est fortis, potensque hanc obligacionem de hoc iure ad ius superius, hoc est ad librum Cracoviensis castri inscripcionem ${ }^{34}$. - Tyle znaczeń

${ }^{34}$ Por. również tytul dzieła L. Lysiak a, cytowanego wyżej w przyp. 24. 
posiada termin ius użyty w liczbie pojedynczej ${ }^{35}$. A może pluralis owego rzeczownika dorzuci walory dalsze?

5.8. Skonstatowaliśmy wyżej, że w singularis ius znaczyło nieraz świadczenia wiejskie na rzecz pana (pkt 4). Takiż sens przybiera najczęściej ów rzeczownik użyty w liczbie mnogiej, iura: 'ciężary wszelakie'. W przywilejach immunitetowych i lokacyjnych od tego znaczenia aż się roi ${ }^{36}$; na to już wielokrotnie zwracano $w$ literaturze fachowej uwage (Lowmiański) ${ }^{37}$. Ten sam walor mają iura w drugiej partii głośnej klauzuli ignorancyjnej.

5.9. W sumie pod piórem średniowiecznych skrybów ius to termin o rozległej liczbie znaczeń. Raz to opłata sądowa, to znów wiejskie czynsze; innym razem sąd lawniczy albo sama lawa, kiedy indziej to sąd wyższy lub najwyższy prawa niemieckiego; wreszcie, w liczbie mnogiej, iura - to najczęściej świadczenia składane przez ludność chłopską księciu czy panu ${ }^{38}$.

5.10. Zdajemy sobie przy tym dobrze sprawę $z$ tego, że w przedstawionym wykazie nie wyczerpaliśmy wszystkich wariantów znaczeniowych owego terminu ${ }^{39}$. W każdym razie pewne jest, że ani ius (sing.), ani iura (pl.) z pewnością nie zawsze należy kojarzyć z prawem, jak się to czyni wielokrotnie.

6.1. Domniemywać wolno $z$ góry, że nie inaczej przedstawi się sprawa, gdy to samo ius wystąpi z jakąś towarzyszącą mu w masie wypadków przydawką rzeczownikową lub przymiotnikową. Ducange notuje takich zestawień powyżej 50 !

6.2. W naszych źródłach średniowiecznych jawi się owo ius nader często $\mathrm{z}$ narodowymi przydawkami przymiotnikowymi, Teutonicum ${ }^{40}$ czy, rzadziej, Polonicum. I wówczas należy się liczyć z polisemią. Bo dlaczegoż chodzić by w nich miało zawsze o niemieckie czy polskie prawo? Przez tylu pisarzy

${ }^{35}$ Charakterystyczny cytat, w którym skryba posłużył się w jednym zdaniu terminem ius $\mathrm{w}$ trzech różnych znaczeniach, Komb. $\mathrm{nr}$ 76, r. 1488: veniens [...] coram nostro banito iudicio primo, secundo, tercio et quarto secundum ius (1), mullo adversario contradicente ius (2) eum decrevit fore et esse bone fame et ipsius pueros; super hoc Nicolaus Pytka posuit ius (3) scabinale.

${ }^{36}$ Również u D łu g o s z a pospolity zwrot: solventes sibi, episcopo, censum et iura cmethonalia consueta (Liber beneficiorum dioecesis Cracoviensis, t. 1, r. 1863, s. 448).

${ }^{37}$ Zauważ, że leges mogą być także równoważne pensiones, SUb 1, nr 101, r. 1206.

${ }^{38}$ Por. M. Ple zi, Slownik laciny średniowiecznej, w którym zestawiono jakąś piętnastke znaczeń. Natomiast Ni e rm a y er zna tylko jedno: 'redevance'; o D u cange' u niżej ust. 6.1.

${ }^{39}$ Por. np. Ab annis prope quingentis per Mieczslaum, principem Poloniae, qui primus et se ipsum et Polonicam seu Lechiticam gentem ab errore vetusto idolatriae ad christianitatis iura reduxit (L. b., 1, s. 5). Tu sens oczywisty - Mieszko I wprowadził chrześcijaństwo.

40 Tylko wariantami jego sq odmiejscowe określniki: ius Magdeburgense, ius Sredense i in. Tak już J. J. M enzel (s. 287): Trotz der verschiedenen Namen sind seine Grundzüge (chodzi o zasady prawa niemieckiego) überall dieselben. 
i przez tyle stuleci używane wyrażenie nie musiało zawierać niezmiennie jednej i tej samej treści ${ }^{41}$. Rzeczywiście owe nagminnie wystẹpujące wyrażenia - ius Teutonicum oraz ius Polonicum - były wieloznaczne.

6.3. W naszych dokumentach trzynastowiecznych, jak zresztą i w aktach pochodzących $\mathrm{z}$ stuleci następnych, wyrażenia ius Teutonicum używa się bardzo często $w$ znaczeniu szczególnym. Stało się ono mianowicie terminem technicznym dla przeprowadzonego wówczas w miastach i na wsi osadnictwa nowego typu. Miało się ono dokonywać według niemieckiego prawa, wedhug niemieckiej modły, iuxta modalum Teutonicum. To znaczenie staraliśmy się ustalić na innym miejscu, wyłuskać istotną jego treść; ograniczyliśmy się przy tym do stosunków wiejskich ${ }^{42}$.

Stwierdziliśmy tam, że pod omawianym wyrażeniem ius Teutonicum kryła się koncepcja wlasności podzielonej, nie znana przedtem w Polsce. Zasadzała się ona na przyznaniu koloniście bardzo szerokich praw rzeczowych na nadanym mu gruncie; tak szerokich, że tylko je za własność poczytać należało.

Wszakże, uznając kolonistę za wlaściciela ziemi, równocześnie poczyniliśmy bardzo poważne zastrzeżenie. Jego własnošć nie była pełna, nie taka, jak ją rozumiało klasyczne prawo rzymskie $\mathrm{i}$ jak to pojmuje ustawodawca dzisiejszy. Prawda, wielki właściciel ziemski cedował osadnikowi rzeczywiście grunt (najczęściej jeden łan) ${ }^{43}$ tytułem wspomnianej własności ${ }^{44}$ (nazwaliśmy ją chłopską), ale dalej zachowywał na nim własność (w opozycji do poprzedniej nazwaliśmy ją pańską) ${ }^{45}$. Wytworzyła się zatem nowa proprietas swoistego typu, typu feudalnego, proprietas kolonizacyjna, którą w literaturze zwie się

41 A. Körmendi sądzi, że treść prawa niemieckiego ulegała zmianie z upływem czasu (op. cit., s. 481). My zaś stwierdzamy, że istniało osobne lowickie prawo niemieckie, zastosowane do kużnicy - jak to wynika z przywileju arcybiskupa gnieźnieńskiego, Jarosława, z 1366 r., dla minera ferri w Bełchowie, $S$. Librowski, Czterdzieści cztery niedrukowane dokumenty arcybiskupa Jaroslawa $z$ lat 1343-1372, [w:] Archiwa-biblioteki i muzea kościelne, t. 52, 1986, $\mathrm{nr}$ 38: obdarowany przywilejem podkomorzy (succamerarius) arcybiskupi, Godko: Insuper iam dictus Gothko kmetones circa se locatos Theutonicali [iure], in districtu nostro Lovicensi servato, iudicabit.

42 J. Matus zewski, Posada chlopska, „Sprawozdania z Czynności i Posiedzeń Naukowych LTN" 1992, t. 2, 46, Lódź 1993, s. 109-117; te nż e Ius Teutonicum..., por. wyżej przyp. 13.

$43 \mathrm{~W}$ praktyce było nieraz ich więcej; por. przywilej lokacyjny z 1291 r., w którym wystawca zastrzega sobie, że chłop może mieć co najwyżej 2-3 łany (Menzel, nr 112).

44 A był to obszar niemały. Flamandzki tan wynosił ca 16,8 ha, frankijski, rzadziej występujący - 24-26 ha; R. Kötzschke, W. Ebert, op. cit., s. 47, 102. Na Sląsku ten drugi wyjątkowy, K. Ty mi e ni e ki, Kolonizacja.., s. 39, przyp. 59.

${ }^{45} \mathrm{~W}$ jednym $\mathrm{z}$ dokumentow czytamy: ...hereditas iure proprietatis, quod vulgariter eigen dicitur, Menzel, (nr 115, r. 1291); akt lokacyjny biskupa wrocławskiego z 1254 r. wyraża się niedwuznacznie: villam nostram [...] contulimus [...] ad locandum (SUb 3, nr 112) - to przykład jeden $\mathrm{z}$ tysiąca. 
posadą chłopską ${ }^{46}$. Istota jej polega na równoczesnym istnieniu dwóch właścicieli jednej nieruchomości ziemskiej, a przytem takich, którzy nie są bynajmniej współwłaścicielami. W swych uprawnieniach bowiem nie są sobie równi. Zakres własności każdego $\mathrm{z}$ nich byl odmienny ${ }^{47}$.

Co zaś przede wszystkim w omawianym stosunku rzuca się w oczy: różnią się owe dwie własności nie tylko treścią - co już dla prawnika ważne - ale dodatkowo hierarchią. Pańska górowala nad chłopską, była nadrzędną (panującą) wobec chlopskiej - podrzędnej (shużebnej). Owa dwoistość uwidaczniała się $w$ praktyce, tym bardziej że obok podległości rzeczowej (gruntów) rodziła się równocześnie $\mathrm{z}$ osadzeniem zależność osobista (servicialis subiectio, SUb $4 \mathrm{nr} 380$, r. 1279) kolonisty wobec pana ${ }^{48}$. Że ją rozumiano jako coś bardzo poniżającego, świadczą wywody autora Księi henrykowskiej, który z naciskiem szczególnym akcentuje, że jego klasztor

46 Pełną analogię w stosunkach miejskich stanowi posada miejska (städtische Häuserleihe).

${ }^{47}$ Por. J. Matuszewski, Posada chlopska, s. 114.

${ }^{48} \mathrm{O}$ tej podległości osobistej kolonisty zapominają $\mathrm{z}$ reguły historycy niemieccy, którzy $\mathrm{w}$ ius Teutonicum (niemieckim prawie) dopatrują się samych dobrodziejstw dla polskiego chłopa, widząc $\mathrm{w}$ nim wielką misję cywilizacyjną! Nie chcą dostrzegać zasadniczego faktu, że cała działalność osadnicza prowadzona była przez wielkiego właściciela ziemskiego, od samego początku do końca $w$ jego interesie, $i$ to wylącznie, że mieściła się ona $w$ ramach immunitetu, którego udzielono... panu. Ten zaś $z$ dobrodziejstw przyznanych sobie przez wladcę nigdy w całości rezygnować nie zamierzał, lecz dzielił się nimi $\mathrm{z}$ kolonistą zaledwie $\mathrm{w}$ takiej czéści, którą uznal za konieczną dla przeprowadzenia lokacji, a dla siebie za możliwą. Z immunitas zaś wiązała się $w$ istocie podległość poddanego panu, który zostawal jego sędzią! Co więcej - pozycja kolonisty była po osiedleniu się słaba, bo osiadał na cudzym gruncie, który cudzym nigdy być nie przestał. Jego własność feudalnie podrzędna, była tylko cieniem pańskiej, nadrzędnej. Prawda - chłop mógł swoją zagrodę bez zgody pana opuścić, ale taka niesubordynacja łączyła się $z$ utratą jednołanowego, a więc około 70-100 morgowego gospodarstwa. W istocie przyshugiwała zatem chłopu wolność zostania z zamożnego kmiecia... żebrakiem! W takiej sytuacji kolonista, choć sam był „ruchomością" i mógł z ziemi pod pewnymi warunkami „ruszyć" legalnie, faktycznie byl z nią związany. Jej bowiem jako nieruchomości, opuszczając wieś, z sobą zabrać nie mógł. W tych wyrunkach - co zrozumiałe - nie miał najmniejszej chęci rezygnowania ze swej zagrody. Czyżby trzeźwo myślący gospodarz, który niejednokrotnie przez dwa, a może nawet trzy pokolenia (weźmy pod uwagę okresy woli 24-, a nawet 30-letniej) mozolił się, by rolnicze nieużytki zamienić $w$ ziemię uprawną, ze swej libertas kiedykolwiek korzystał (nie bierzemy pod uwagę wypadków skrajnych)? Omawiając zbiegostwo kmieci, trzeba zawsze o jednym pamiętać: niecale rolnictwo polskie stosowato u siebie prawo niemieckie. Zawsze utrzymywał się dalej poiski system, ktory uchwycil w tomie pierwszym swego Liber beneficiorum Iwan D lug o sz: Item habet dicta villa quatuor laneos cmethonales, datos agricolis non in haereditatem perpetuam, sed ad tempus, quoniam singulis annis fit eorum locus, alias osadzenye, a festo Nativitatis Christi (por. ibidem, s. 539, 542, 543 przykłady jeszcze luźniejszego osadzenia kmiecia: habet tamen facultatem pro omni tempore custos sancti Michaelis cmethonem praefatum de agro praediali deponere). Tego typu osadnictwo ma przypuszczalnie na myśli późniejszy ustawodawca, walczący ze zbiegostwem kmieci. Być może też, że z czasem pozbawiono prawo niemieckie owego istotnego elementu - chłopskiej, własności (podrzędnej), albo też wobec nadmiernych wymagań pańskich straciła ona dla poddanego swój pierwotny walor. Podrzędny właściciel przestał przywiązywać do niej wagę: 
nie był niczyim poddanym; nie płacił bowiem czynszu nikomu i nigdzie, nulli, nec umquam ${ }^{49}$.

Stworzenie własności podzielonej miało przyczynić się ad fructuose melioracionis augmenta reduci [...] ad usus redigi meliores (Menzel, $\mathrm{nr}$ 98), a więc zwiększyć produkcję zboża, mięsa, mleka i jaj. Przy tej reformie - co akcentujemy ponownie - wlaściciel ziemski kierowal się wyłacznie interesem osobistym.

6.4. $\mathrm{Z}$ lokacją iure Teutonico wiąże się libertacja ab omni iure Polonico sine exceptione w slynnym dokumencie lubiąskim $\mathrm{z}$ roku 1175 (SUb $1 \mathrm{nr} 45$ ). Znaczyło to, że polscy chłopi klasztorni non cogantur alii cuiquam aliquid solvere vel servicium aliquod exhibere. Nadane równocześnie gościom ius Teutonicale znaczy: ut sint inmunes ab angariis, que fieri solent Polonis secundum consuetudinem terre, que vulgo dici solent: povoz, prevod, zlad et a solucionibus, que solent exigi, sicut est: stroza, podvorove, swetopetre et similia $^{50}$.

Niemal tak samo definiuje się ius Teutonicale w dokumencie nadanym gościom klasztoru św. Wincentego we Wroclawiu: ...ut sint inmunes ab angariis, que fieri solent Polonis secundum consuetudinem terre, que vulgo dici solent povoz, prevod, slad, preseka, et a solutionibus, que solent exigi, sicut est strosa, podvorove et his similia, z zastrzeżeniem dla księcia dwóch mierzyc pszenicy i owsa (SUb 1 nr 293, r. 1228). Zwrot nulli iuri Polonico sint subiecti wyjaśniony zostaje $\mathrm{w}$ innym dokumencie tak: ut est de podvodis, privodis, vestigiis fugitivorum indagandis et aliis consimilibus, (SUb $2 \mathrm{nr} 86$, r. 1234). Polacy, osadzeni iure Teutonico, ad nullum ius Polonicum vel solucionem vulgarem pertrahentur (SUb $2 \mathrm{nr} 339, \mathrm{r}$. 1247). In iure Teutonico vel alio modo, qui sibi videbitur expedire (SUb $1 \mathrm{nr} 222$, r. 1222). - Innymi słowy, Romani i Niemcy, jak też inni goście osadzeni zostają in iure et libertate Theutonicali (SUb 2 nr 34, r. 1233, nr 193, r. 1240). Przykladów tego typu bezlik. - A więc ius Polonicum w cytowanych kontekstach to opłaty uiszczane przez ludność narodowości polskiej na rzecz księcia. Pisarzowi z prawem nie kojarzyło się tu ono w ogóle; ius Teutonicum zaś jest dla niego równocześnie ewidentnie synonimem libertas, a także - bo to na jedno wychodzi - równoważnikiem immunitas!

Tak sprawa wygląda od strony wystawców przywilejów, wladców. Stąd w literaturze polskiej ukuta terminologia: immunitet czysty oraz immunitet

nic $z$ niej nie mial, ekonomiczne negativa przerosly positiva! Walkę $z$ uprawnieniami przyznanymi koloniście rozpoczął pan, wstawiając do przywilejów lokacyjnych klauzulę ignorancyjną. W końcu - wiemy - doszło do wtórnego, zaostrzonego poddaństwa!

49 Por. J. M at uszewski, Legniccy kumotrzy, CPH 1993, t. 44, s. 154.

${ }^{50} \mathrm{SUb} 1$, nr 211, r. 1221. Zauważ przeciwstawienie terminów angarie (powóz, przewód, ślad) i soluciones (stróża, podworowe). 
pod formą lokacji na prawie niemieckim ${ }^{51}$. $\mathrm{O}$ tych tak charakterystycznych kontekstach często się zapomina i interpretuje wspomniane określenia tak, jakby chodzilo $w$ nich o niemieckie (czy polskie) prawo ${ }^{52}$.

6.5. Stwierdziliśmy zatem, że ius Teutonicum rozumiano jako własność podzieloną (pkt 6.2), że bywa ono również synonimem wolności od świadczeń (pkt 6.3-6.4). Miało ono $w$ obydwu wypadkach znaczenie przenośne. Wszakże to nie jedyne walory owego wyrażenia.

Pod ius Teutonicum ujeły dokumenty również - jak się wydaje - zespół norm niemieckich $\mathrm{w}$ ogóle, a więc niemieckie ius iudiciarium. Takiego rozumienia nie odważamy się wyłączyć. Co więcej, wydawałoby się nawet dziwne, gdyby wystawca dyplomu czy jego odbiorca, a tym bardziej skryba, nie podkładali nigdy pod owe wyrażenie literalnej treści. Ona narzucała się sama. I to nawet $\mathrm{w}$ pierwszej linii: ius Teutonicum to $\mathrm{w}$ ogóle prawo stosowane przez Niemców w jakiejkolwiek dziedzinie życia.

Takie rozumienie niemieckiego prawa jest nader częste u nas w stosunkach miejskich. Ale nie wydaje się ono również obce wsi. Tak niewątpliwie rozumie owo wyrażenie przywilej Henryka III z $1252 \mathrm{r}$. (SUb $3 \mathrm{nr} 43$ ): prout Theutonica iuris sententia iudicare decreverit. I wiele innych ${ }^{53}$.

6.6. Ale, i co więcej, nawet wówczas, gdy w dokumencie faktycznie o niemieckim ius iudiciarium mowa, sens wypowiedzi nie musi być zawsze jeden $\mathrm{i}$ ten sam. Zastanowić się więc musimy, o jakie normy chodzi, z jakiej one dziedziny, czego dotyczą - ustroju sądowego, prawa procesowego, czy prawa materialnego. Uprzytomnijmy sobie sytuacje, w których pojawia się w naszych aktach owo ius Teutonicum (ewentualnie inne jego warianty, jak: ius Alemanicum, Franconicum, Flamingicum, czy tak częste ius Maydeburgense lub Sredense) w znaczeniu dosłownym.

6.7. Raz zatem wspólcześni myśleli o jednym walorze (o niemieckich regułach osadniczych oraz o wprowadzanych wolnościach podatkowych), to znów o innym ustroju sądu, to wreszcie o normach niemieckich generalnie, proceduralnych lub materialnych) ${ }^{54}$.

${ }^{s 1}$ Por. Z. Wojciechowski, op. cit., s. 699. Za nim poszliśmy z górą pół wieku temu w swym Immunitecie, s. 113-119.

52 Por. jeszcze inne oryginalne użycie terminu: villam suam olim ritu Polonico Wadochowitz, nunc vero iure Theutonico Wisintal vulgariter nuncupatur (Ks. Hent., s. 334) - zwraca na nie uwage K. Tymieniecki, Z dziejów rozwoju wielkiej wlasności na Ślqsku w wieku XIII, Poznań 1926, s. 285. Najchẹtniej jednak uzupehnilibyśmy tekst trzynastowiecznego autora: ...nunc vero iure Theutonico [locata] Wisintal vulgariter nuncupatur, wyłączając $w$ ten sposób jedno znaczenie ius Theutonicum.

${ }^{53}$ Oto cytat Du c a nge' a zaczerpnięty z Diarium belli Hussitici: Item quod iura paganica et Teutonica, que non concordant cum lege Dei, tollantur.

${ }^{54} \mathrm{~W}$ tych warunkach nie zdumiewa nas to, że hasło ius Teutonicum nie znalazło sie w najnowszym Handwörterbuch zur deutschen Rechtsgeschichte (1978). 
6.8. Dorzućmy spostrzeżenie dalsze. Podejrzewamy, że współcześni nie zawsze rozgraniczali owe walory dokładnie, choć to rzeczy ewidentnie różne, i bezwiednie przesuwali się od jednego pojęcia do drugiego ${ }^{55}$. Przy takim uderzającym w oczy braku dystynkcji zrodzić się moglo u nich przekonanie, że przywilej zasadźczy nadawał chłopom-kolonistom nie tylko ius Teutonicum lokacyjne, własność podrzęnq̨ gruntu, ale równocześnie obdarzal ich niemieckimi normami prawnymi, a tym samym przenosił ich $\mathrm{Z}$ sądowego rodzimego prawa polskiego na obce - niemieckie. $Z$ chwilą lokacji doszłoby tym samym na wsi polskiej do recepcji niemieckiego ius iudiciarium oraz do jego zrozumialego następstwa - likwidacji prawa polskiego $^{56}$.

6.9. Przy wskazanym braku precyzji źródeł nie zdumiewa nas fakt, że nie tylko Polacy doby przedrozbiorowej, ale i czytelnicy średniowiecznych dokumentów, historycy, dali się częstokroć zasugerować ową wieloznacznością terminologiczną. Powszechnie przyjmują także oni, że ius Teutonicum wprowadziło do Polski własność podzieloną - $\mathrm{z}$ jednej strony. A równocześnie wyrażają przekonanie, że obok wskazanej melioracio terre zawierało ono w sobie treść dalszą, niemieckie ius iudiciarium: ustrój sądowy oraz prawo prywatne (lacznie $\mathrm{z}$ karnym), materialne $\mathrm{i}$ formalne $-\mathrm{z}$ drugiej ${ }^{57}$. Zatem na polskiej wsi w opinii historyków dojść miało w 13 . w. do recepcji niemieckiego prawa. Communis opinio doctorum pokryła się zatem $\mathrm{z}$ poglądem rzekomo wypowiadanym expressis verbis w średniowiecznych aktach. - Rozpatrzmy te zagadnienia po kolei.

${ }^{55}$ Nie jesteśmy również przekonani o tym, by autorzy klauzuli ignorancyjnej mieli w swej świadomości wszystkie rozpatrywane przez nas warianty znaczeniowe. Wszakże jedno nie ulegało dla nich wątpliwości: wiedzieli dobrze, co panowie dla siebie rezerwują.

${ }^{56}$ Rzuca się to $\mathrm{w}$ oczy, szczególnie u niemieckich historyków, dla których ius Teutonicum jeden posiada walor: niemieckie prawo. I $\mathrm{z}$ dumą piszą o jego zwycięskim pochodzie w ramach Ostbewegung! Oto jaskrawe sformulowanie K. R edlich: Das [deutsche] Recht und die damit verbundene soziale Stellung war das eigentlich Trennende, wer deutsches Recht erhielt, verlor damit formal und im Laufe der Zeit wohl auch praktisch seine slavische Nationalität (Nationale Frage und Ostkolonisation im Mittelalter, Berlin 1934, s. 52). Również rolę materialnego prawa (niemieckiego) w Polsce wyolbrzymiają R. Kötzschke, W. Ebert (op. cit.), jak i A. Brackman n, Magdeburg als Hauptstadt des deutschen Osten, Leipzig 1937, oraz Menzel.

57 Por. J. Matu szewsk i, Recepcja prawa niemieckiego w Polsce, „Sprawozdanie PTPN" 1965 , nr 2, s. 244. Jeszcze H. F. S ch mid rozumie ius Teutonicum jako „Verbreitung des deutschen Rechts, in erster Linie des Privat-, Straf- und Prozeßrechts, dann des Lehnrechts, des Bergrechts und anderer Teile des öffentlichen Rechts im ursprünglichen Geltungsgebiet polnischer Rechtsordnung" (Die Rechtlichen Grundlagen der Pfarrorganisation auf westslavischem Boden und ihre Entwicklung während des Mittelalters, Weimar 1938, s. 349). Równocześnie stwierdza: ,,...wie wenig die Nationalitätsverhältnisse in derartigen Vorgängen für den Rechtshistoriker faßbar sind" (ibidem, s. 350, przyp. 3). 
7.1. Stwierdziliśmy wyżej, że samo ius znaczyło nieraz sąd ławniczy (por. 5.5). Ten sam walor przypisują teksty wyrażeniu ius Teutonicale (T. $\mathrm{nr}$ 356). Chodziło zatem o niemiecki ustrój sądowy. Nasuwa się wręcz pytanie, czy w rozumieniu wystawcy aktu lokacyjnego, jak też zasadźcy i samych kolonistów, nadanie ius Teutonicum do tego się nie ograniczało (obok - oczywiście - wlasności podrzędnej): własny, z współmieszkańców-plebejów złożony trybunał wiejski. Resztę, a więc niemieckie prawo formalne i materialne - być może - wmawiają źródłom historycy? Owo samorządne sądownictwo stanowiłoby zatem novum, które zawdzięczała wieś polska niemieckiemu prawu, novum obejmującym - powtórzmy - wszystkich osadników lokowanych na tym prawie - zarówno Niemców, jak i Polaków. Ale też, być może, novum jedyne! Przejęcie obcego ustroju sądowego było rzeczą prostą.

7.2. Do pełnego obrazu brak nam wszakże jednej wiadomości. Nie wiemy nic o tym, jak było zorganizowane na wsi polskiej sądownictwo poimmunitetowe przed pojawieniem się prawa niemieckiego ${ }^{58}$. Pełnić je mial w immunizowanych dobrach - wiadomo - pan lub jego zastępca (nuncius). Niestety, po ich działalności nie pozostało żadnych śladów - brak protokolów z posiedzeń sądowych. Nie wiadomo, czy je w ogóle prowadzono; wydaje się to zresztą mało prawdopodobne, zadowalano się w nich raczej decyzją ustną.

7.3. Nasuwa się dalej problem, czy owo poimmunitetowe polskie sądownictwo wiejskie było jednoosobowe (wyrokował sam pan lub sam nuncius), czy raczej należy się liczyć z uczestnictwem chlopskich asesorów. A jaka przy tym była ich rola? Czyżby nie odbiegała od tej, jaką przypisuje sądom polskim nasz Najstarszy Zwód Prawa Polskiego: ouch zy wissentlich, daz der polesche richter nicht scheppen pflegit zcu haben. Zyt her abir nucze lute by im, dy leet her zcu im unde leget in dy rede vor. A zatem komplet taki nie stanowił sądu lawniczego w ścisłym tego słowa znaczeniu, skoro jego asesorowie nie mieli glosu stanowczego. Informacja NZ nie pozostawia co do tego jakichkolwiek wątpliwości: Unde dunkit in ir keynis rede recht, dornoch richtet er. Behaget im abir ir keynis rede, zo richtet her noch synem zynnen, zo her rechteste kan. Jednakowoż przy całkowitym braku źródeł nie jesteśmy $w$ stanie orzec, czy rzeczywiście przytoczone teksty znajdowały zastosowanie równiez $w$ polskim sądownictwie poimmunitetowym, znajdującym się w ręku osoby prywatnej, pana wsi. Czy przypadkiem analogia frankońska - immunista tamtejszy byl tylko przewodniczącym; obok niego zasiadali rachimburgi lub scabini $\mathrm{z}$ glosem stanowczym - nie byłaby tu właściwsza?

$58 \mathrm{Z}$. W ojciechowski nosił się z zamiarem opracowania tego zagadnienia $\mathrm{w} 2$. tomie Historii Ślqska; por. pracę przytoczoną wyżej, s. 715 , przyp. 1. Nie został on nigdy zrealizowany. 
7.4. Tym bardziej że historyk skłonny wątpić w gorliwość sędziowską jaśnie pana czy jego zastępcy! A w takim razie może i chłopi siedzący na prawie polskim w dobrach immunizowanych sądzili się nieraz sami? Może pod przewodnictwem starosty, który był der edilste in dem dorffe, albo włodarza, adir der vloder, daz ist der scheffer, der mag synen stab in den henden wol habin vor synen herren, wen her entwertet?

7.5. Gdy z braku źródeł na te wszystkie wątpliwości odpowiedzieć nie możemy, za pewny wkład niemieckiego prawa poczytać musimy zaprowadzenie sądu lawniczego, w którym przewodniczyl soltys, ale siedmioosobowej lawie przyslugiwał głos stanowczy. Nie zapominamy wszakże o utrzymaniu nadzorczych uprawnień pana (iudicia magna).

7.6. Zachowane źródła nie informują nas o tym, w jakim stadium osadnictwa trybunał wiejski zebrał się po raz pierwszy. Ksiegi lawnicze traktują go jako instytucję w pełni zorganizowaną, funkcjonującą od dawna. Domyślać się jedynie możemy, że owe chłopskie sądy działać zaczęły $\mathrm{z}$ chwilą zaawansowania procesu osadniczego.

7.7. Sądy ławnicze wiejskie kompetentne były wobec ludności poddańczej, przede wszystkim miejscowej. To ich zadanie podstawowe. Rzeczywiście gros spraw toczy się w nich między miejscowymi chłopami. Nieraz wszakże jawią się przed nimi chłopi $\mathrm{z}$ obcych wiosek, a także, acz sporadycznie, mieszczanie, księża ${ }^{59}$ i kościoły ${ }^{60}$, a nawet szlachta ${ }^{61}$. A więc generalnie

${ }^{59}$ (Krzem. nr 45, r. 1453): dy sint burgin wurdin vor IX marc dem pharrer von Crasznepolu; (ibidem, nr 196, r. 1459): wer czewgin, wy das ist kommen Hannus Becken mit dem pharrer vor unser hehegte banck und do hot Hannus Becke vormanet den pharrer, ap her ym bekenthe VII firdunge; (ibidem, nr 415, r. 1469): wir czewgin, wy das ist kommen der pharrer mit Matis Crassznerin vor wnser gehegte, vnd do hot der pharrer dy Matis Crassznerin vormanet, ap her ir den fleckin hette beczalth gancz vnd gar, vnd do hot gestandin Matis Crassznerin [...] vnd hot dem pharrer das bekanth, das her ir eyne beczalunge hot gethoen, vnd hot dem pharrer den fleckin frey und ledig geloen von ir [...]; und dor obir hot der pharrer sss gelet.

$\omega^{\circ}$ (Krzem. nr 106, r. 1450): do von salder kyrchen VI grosschen warden; (ibidem, $\mathrm{nr} 214$, r. 1460): wir czewgin, wy das seynt komen dy kyrchenbytter vor vnser gehegte banck und habin vormant Bartisch Rottin [...], so sal her der kyrchen czynssen von seynes swers tawyn, hot her yn bekant..; vnd dor obir han dy kyrchenbytter iren scheppen schelling gelegit; (ibidem, $\mathrm{nr} 405$, r. 1469): vnd der kirchin sal werdin I firdung; (ibidem, $\mathrm{nr} 586, \mathrm{r} .1478$ ): vnd wen dy kirchen vor wirt hebben; (ibidem, $\mathrm{nr} 713, \mathrm{r} .1481$ ): vnd off dy leczte gelde sal werdern der kirchen eyn marg, und dornoch, wen dy kirchen gehebet; 1452: Item debita ecclesie, ut sequitur (ibidem, nr 736-738); por. Krzem., s. 48*.

${ }^{61}$ Przykładów dostarcza księga trześniowska: (nr 356) quomodo veniens generosus dominus Iacobus, heres de Iaczymyrz et de Bszanka, affectavit ius, secundum quod dominus super causam predictam, pro qua postulavit, fecit. Generosus dominus Iohannes Szobyenszky, heres de Crzesznyow concessit et dedit sibi ius generoso domino Iacobo, heredi de Bszanka, ius Teutunicale, propria in persona existens, et heres eum suscepit et interfuit ad diem deputatum, prout posita fuit inter ipsos, et hic ius Teutunicale suscepit et stetit coram iudicio celebrato in propria persona et cum 
wszyscy, których interesy jakoś wiązały się z daną wsią, którzy, mając roszczenia do siedzącego $w$ niej chłopa, pozywają go do sądu dla niego właściwego, sądu osady, w której mieszka.

7.8. O tym, że lawniczy sąd wiejski stanowi iudicium Teutonicum, przekonani byli wspólcześni. Oto kilka informacji z końca 15. i z początku 16 . w.: (T. nr 328, r. 1479), ius Theutonicum Meydeburgense, (T. nr 689 r. 1528), profitentes universis, quibus expedit, singulatim tamen laboriosis, iudici et iuratis iuris Theutunici Meydeburgensis ville Trzesznyow. Zwać się już będzie $\mathrm{w}$ dobie nowożytnej prawem (w znaczeniu sądu) trześniowskim (T. nr 807 1536 r., 15221603 r., 15251602 r.). - I to wydaje się historykowi również niewątpliwe: ustrój wiejskiego sądu ławniczego, iudicium bannitum, parvum czy magnum, recypowany z Niemiec, był sądem niemieckim ${ }^{62}$.

7.9. Skłonniśmy prawu niemieckiemu przypisać również wprowadzenie ksiąg sądowych.

7.10. Wszakże - co wiecej - panuje również przekonanie, że tenże sąd ławniczy jest nie tylko trybunalem niemieckim ${ }^{63}$, lecz że stosuje się w nim niemieckie normy. Czy rzeczywiście tak bylo, czy wprowadzenie sądów ławniczych znaczyło przejęcie prawa niemieckiego? Zobaczmy, co mówią na ten temat teksty. Wpierw jednak zapytajmy, jakimi normami rządzili się koloniści dawniej, jakie ius iudiciarium obowiązywało osadzaną iure Teutonico ludność, przed objęciem przez nią w Polsce gospodarstw na nowych, „niemieckich" zasadach.

8.1. Stwierdziliśmy wyżej, że o recepcji obcego prawa możemy mówić wówczas tylko, gdy mamy do czynienia $\mathrm{z}$ osadnikami-Polakami. A takie osadnictwo najczęstsze, wręcz przemożne. Ono właśnie było z pewnością zjawiskiem masowym. Tu zatem leży problem: czy prawo niemieckie przyjmowali koloniści nieniemieccy, a więc głównie osadzający się iure Teutonico

suis actoribus et traxerat se secundum ius servare et ius Teutunicale in prefata causa ius indicavit. Spór, który toczył się między dwoma szlachetkami przed sądem ziemskim, trafił również do sądu ławniczego w Trześniowie. Okazuje się bowiem, że zastępca procesowy posuit duplum ius, terrestre et Almanicum (T. $\mathrm{nr} 437, \mathrm{r}$. 1495). Rozumiemy to wyrażenie jako dwukrotne uiszczenie opłaty sądowej: raz - trybunałowi ziemskiemu, drugi raz - wiejskiemu sądowi prawa niemieckiego. Widocznie wciąnięto $w$ spór oba trybunały. Jaskrawy to przykład na brak ścisłego rozdziału kompetencyj między sądami.

${ }^{62}$ Por. wyżej ust. 7. 1. Zanotujmy, że mimo nadania prawa niemieckiego, nie kreowano sądu ławniczego we wsi kuźniczej - Bełchowie. Kmieci sądzi tam podkomorzy arcybiskupi - Godko, cum aliquo nostro homine [arcybiskupa], ad hoc specialiter vocato; natomiast familiares vero suos quoscunque idem Gothko solus habebit iudicare (por. wyżej przyp. 41).

${ }^{63}$ Charakterystyczne, że w prowadzonej po niemiecku księdze ławniczej Krzemienicy, nie wspomina się ani razu o tym, że urzęduje tam sąd niemiecki; we wsi, zaludnionej przez Niemców, wydawało się to oczywiste. 
tubylczy lud polski. To zatem kwestia istotna: czy chłop polski równocześnie $\mathrm{z}$ lokacją, a więc - zgodnie $\mathrm{z}$ naszym rozumieniem zjawiska - $\mathrm{z}$ przejściem na nowy system gospodarczy (własność podzielona), recypował niemieckie normy prawne. Wiemy już, nie bylo tu wymogu koniecznego (por. 2.2). A czy w istniejących warunkach przejście na nowy, obcy system prawny było $\mathrm{w}$ ogóle możliwe? Zwłaszcza że chodziło o recepcję zwyczajowego prawa! Czy rzeczywiście do niej dochodziło? Ponownie zadajemy sobie pytanie: jakimi rządzili się polscy chłopi normami przed lokowaniem ich iure Teutonico?

8.2. Przywileje immunitetowe - stwierdziliśmy wyżej - prawem materialnym nie zajmowały się nigdy. One widocznie nie przeprowadzały w nim żadnych zmian, co wydaje się naturalne. Wobec czego - wnioskujemy: chłopi polscy w dobrach immunizowanych rządzili się nadal prawem polskim.

8.3. Niestety, również dokumenty lokacyjne dla prawa prywatnego nie przynoszą nic! A pamiętamy stale o tym, że historia nie jest nauką, dla której starczyłyby argumenty rozumowe.

8.4. Szczęściem zwrócić się możemy do innej kategorii źródel, źródeł związanych - co istotne - najściślej $\mathrm{z}$ kolonizacją iure Teutonico, do wiejskich ksiąg lawniczych. Dzięki nim - spodziewamy się - dowiemy się czegoś o prawie formalnym i materialnym stosowanym w sądach wiejskich ${ }^{64}$. Pisemne protokoły $\mathrm{z}$ posiedzeń owych sądów, a więc akta praktyki, pozwolą nam może na dokonanie pewnych obserwacyj. Od nich oczekujemy odpowiedzi na nurtujące nas pytanie: czy w Polsce średniowiecznej rzeczywiście wraz $\mathrm{z}$ osadnictwem iure Teutonico, którego głównym celem - podkreślenia tego nigdy nie dosyć - była reforma rolna, melioracio terre, czy równocześnie dochodziło do Aufnahme des deutschen Rechts przez polskich chłopów. To zagadnienie pasjonujące.

8.5. Zaglądając do wiejskich ksiąg lawniczych, zauważamy rzucającą się w oczy różnicę w chronologii wspomnianych dwu kategorii źródeł. Podczas gdy dokumenty prawa niemieckiego zaczynają płynąć od początku 13 . w., zachowane wiejskie księgi ławnicze są o wiele późniejsze; najwcześniejsze pochodza z pierwszej połowy 15. w. (najstarsza w Polsce drukowana księga lawnicza, ze wsi Krościenko, zawiera protokoły $\mathrm{z}$ posiedzeń dopiero od 1408 r.) i ze stuleci następnych. Zwracamy na to uwage na innym miejscu ${ }^{65}$. Ale też uprzytamniamy sobie, że wiek 13 . bynajmniej nie zakończył procesu

${ }^{64}$ Rozprawy sądów lawniczych miały się odbywać w każdej wsi, jak o tym świadczą postanowienia przywilejów lokacyjnych, przyznające zawsze soltysom prawo poboru $1 / 3 \mathrm{kar}$ sądowych, co jest regułą nie znającą wyjątku. Ale nie wszędzie prowadzono protokoły, a jak rzadko się one zachowały!

65 J. Matuszewski, Ius Teutonicum..., s. 225-226. 
osadniczego, że trwał on dalej przez następne stulecie. A i ono nie było jego kresem: istnial on zawsze. Od późniejszych lokacji księgi lawnicze już tak bardzo czasowo nie odbiegają. Czujemy się zatem upoważnieni do oparcia się również na nich. Co one przynoszą?

8.6. Podstawą dla nas będzie wyraźna wskazówka w protokole, że wyrok opiera się na prawie niemieckim. Zdarza się to jednak nieczęsto. Nawet podkreślić trzeba wręcz przypadkowość zanotowania faktu, że wyrokuje się zgodnie $\mathrm{z}$ regułami prawa niemieckiego. W dużej liczbie wyroków nie powołano się na nie w ogóle (o opłacie schöffenschilling mówi się przecież w każdej zapisce!), albo wskazuje się krótko na stosowanie procedury iuxta iuris formam (T. nr 80 r. 1445), secundum iuris formam (T. nr 87 r. 1447) bez dalszej wskazówki, o jakie prawo chodzi. Widocznie podanie w protokole informacji o zastosowaniu $w$ konkretnym wypadku niemieckiego prawa zależało od humoru skryby!

8.7. Nie łudzimy się co do tego, że dojdziemy przez wspomnianą lekturę do pelnej rekonstrukcji niemieckich norm prawnych. Zwyczajowych reguł nie da się odtworzyć $w$ całości ${ }^{66} \mathrm{z}$ prostego powodu: nie znano $\mathrm{w}$ średniowieczu praktyki uzasadniania wyroków, lecz zadowalano się zanotowaniem w protokole samej sentencji. Sądzimy wszakże, że nawet $w$ tych warunkach jakiś skromny wynik osiągniemy. Taki, który będzie stanowil uzasadnienie wystarczające dla tezy o recepcji materialnego prawa niemieckiego przez chłopów polskich. Przestanie ona być gołosłowna, jaką jest dotąd.

9.1. Zapytajmy wpierw, przy jakiej okazji miało się to niemieckie prawo zwyczajowe $w$ wiejskich sądach ławniczych przejawiać. Przypatrzmy się sprawom rozpatrywanym przez nie $w$ dobie średniowiecza. Dadzą się tu wydzielić dwie zasadnicze grupy. W drukowanych piętnastowiecznych księgach, które przejrzeliśmy, jedną $\mathrm{z}$ nich stanowiły zagadnienia niesporne. Protokoły omawiane stanowią więc hipoteczne zapisy podrzędnych właścicieli gruntów, poddanych. Wiejskie ksiegi ławnicze są tym samym chłopskim odpowiednikiem szlacheckich ksiąg ziemskich.

9.2. Druga poważna grupa sporów, którymi się sądy wiejskie zajmowały, dotyczyła czci chłopskiej. Ograniczano się wówczas do stwierdzenia faktu uczciwości obwinionego: ich gabe dir nyrkeyne scholt wenne libe vnd gut (Krzem. nr 107), das her schon vnd fertig vor gehegter bank vnd ym keyn solt nicht gebe, das her schon vnd fertig were vnd ym keyn scholt nicht gebe (ibidem, nr 302), wenne was do fromlich vnd erberlich were (ibidem, $\mathrm{nr} 305$ ), das her sal seyn als eyn ander gutt man (ibidem, $\mathrm{nr}$ 475), das ym keyne man scholt nicht gebe, wen was do fromlich vnd erberlichen mochte geseyn,

${ }^{66}$ Inaczej J. W y r o z u m sk i, op. cit. 
vnd stet alz eyn fromer man, dar do hendrem vnd awch furen nisnichsten hot alz eyn fromer man (ibidem, nr 550). Odpowiednik laciński tego wyrażenia brzmiał: pan oczyszcza poddanego z zarzutu kradzieży ${ }^{67}$, oświadczając: est bonus homo, sicut prius (T. nr 86, r. 1447); et est tamquam unus in communitate bonus et bene conservatus (Wara $\mathrm{nr} 66, \mathrm{r} .1467)^{68}$.

Te dwa zagadnienia, kwestie niesporne i oczyszczanie chłopskiej czci, stanowiły miażdżacą liczbę spraw w znanych nam księgach wiejskich. W sumie składały się one niemal na $100 \%$ spraw. Jakżeż tu niewiele okazji dla okazania znajomości prawa w ogóle, a tym samym i prawa niemieckiego!

9.3. Może ta kwestia przedstawi się inaczej przy rozpatrywaniu spraw karnych. Nie przyjrzeliśmy się temu problemowi bliżej; w wykorzystanych zapisach średniowiecznych liczba ich znikoma. Być może, sytuacja ulegnie zmianie $w$ dobie nowożytnej, gdy Groicki $z$ swymi pracami pisanymi wyłącznie po polsku (r. $1558-1559,1562,1567)^{69}$, a zwłaszcza Szczerbicz z swym polskim przekladem prawa majdeburskiego (r. 1581) ${ }^{70}$ mogli trafić nawet do społeczności wiejskich ${ }^{71}$.

10.1. We wsi osadzonej przez Niemców z soltysem Niemcem, niemiecka lawa to rzecz oczywista. Oczywistą również rzeczą stosowanie prawa niemieckiego ${ }^{72}$. Ale wiemy, że prawa niemieckiego udzielano głównie wsiom zasiedlonym przez chłopów polskich, lokatorami byli często również Polacy, a już tejże narodowości byli w miażdżącej większości panowie (poza cystersami proweniencji niemieckiej). Jaki zatem był skład sądu ławniczego w polskiej wsi osadzonej na prawie niemieckim?

10.2. Oto najstarszy, jaki znamy, skład sądu wsi Trześniowa z 1419 r. Przewodniczy mu generalis Iohannes - wójt, noszący imię kalendarzowe, a zatem neutralne. Ale niedwuznaczne narodowościowo są miana siedmiu

${ }^{67}$ Kradzież rozumiano szeroko, podciągając pod nią nawet uchylanie się od obowiązku mlewa w młynie pańskim: expurgavit innocenciam suam pro eo, quia fuit inculpatus tanquam pro furticinio, quasi ultra preceptum heredis in alieno molendino molendinavit $(\mathrm{T}, \mathrm{n} \times \mathrm{82}, \mathrm{x} .1445)$.

${ }^{68}$ Można było również oczyścić się, przedstawiając odpowiednie pismo: portavit litteram: testimonialem de Blisiwe, videlicet conservatoriam (T. $\mathrm{nr} 88, \mathrm{r} .1447$ ).

${ }^{69} \mathrm{~S} . \mathrm{Kutrze \textrm {b } a}$, Historia źródel dawnego prawa polskiego, t. 2, s. 278-282, oraz PSB, t. 8, s. $628-629$.

${ }^{70}$ S. Kutrzeba, op. cit., s. 213 .

${ }^{71}$ Nie zajmujemy się już kwestiq, jaki wpływ na stosowanie prawa niemieckiego w sadach: wiejskich wywarło nadanie przez Zygmunta Starego thumaczeniu łacińskiemu Jaskiera moc obowiązującej we wszystkich miastach i wsiach (r. 1535), por. S. Kutrzeba, op. cit., s. 212 oraz PSB, t. 11, s. 60-62. Czyżby już wówczas wygasł analfabetyzm na wsi polskiej (For wyżej ust. 3.2)?

${ }^{2}$ Tak już J. Bardach, Historia Paristwa i prawa Polski, t. 1, Do polowy XV wieku, Warszawa 1964, s. 277. 
lawników (scabini, iurati): (1) Thomek Iachnicz, (2) Jan Kuna, (3) Petrus Bugel, (4) Swanch Witkow, (5) Iacobus Kutha, (6) Woytek Sanoczicz et (7) Jan Squarlo ${ }^{73}$. Zatem wyłącznie Polacy. Posługiwali się oni tedy na rozprawach językiem polskim, czego zresztą dowodzą wtrẹty polskie, dodawane do łacińskiego tekstu. Niemieckiego raczej nie znali wcale ${ }^{74}$.

10.3. Oczywiście w przedstawionej w punkcie poprzednim sytuacji najczęściej nikt $z$ członków sądu ławniczego nie znał też prawa niemieckiego. Gdzież by się go nauczyli? Toż to ewentualność - stwierdziliśmy wyżej - wręcz nieprawdopodobna! A w takim razie kierowali się oni - jeśli nie aequitas, co najnaturalniejsze - to materialnym prawem polskim, polskimi consuetudo, mos et ritus! $!^{75}$

11.1. W poprzednich wywodach braliśmy pod uwage sytuacje proste, w Polsce chyba najczęstsze, mianowicie skład sądu czysto niemiecki lub czysto polski, gdy zarówno sołtys, jak i koloniści byli bądź Niemcami, bądź Polakami. W praktyce dochodzić musiało niejednokrotnie do komplikacji, przy osadnictwie powstawały $\mathrm{z}$ pewnością sytuacje mieszane.

11.2. Weźmy pod uwage następującą: osadnikami byli chłopi polscy i $\mathrm{z}$ nich - siłą rzeczy - składała się ława, lecz zasadźcą był Niemiec. Dochodzić musiało między nimi do prawnego konfliktu. Co decydowało o jego wyniku, autorytet przewodniczącego, soltysa-Niemca, czy liczba wynajdujących wyrok siedmiu ławników-Polaków? W źródłach na to pytanie odpowiedzi nie znaleźliśmy.

${ }^{73}$ T., s. 31, nr 1. Miana polskie występują również w składzie późniejszych sądów, np. z 1428 r. Jako viceadvocatus jawi się wówczas Iohannes Gostwy; ławnikami byli: Nicolaus Sypkin, Gregorius Grabecz, Nicolaus Pelcherz, Stephanus Thabyssowycz, Andreas Matynicz, Petrus Vrak, Iohannes Twdnowycz. Podobny polski skład następnych ław. Toż mi znawcy prawa niemieckiego!

${ }^{74}$ Orientował się w tym doskonale Zygmunt August. Wcielając aktem z 27 maja 1569 ziemię wołyńską do Korony, postanawik, że w sądach grodzkich i ziemskich ksiegi ruskiem pismem pisane $i$ odprawowane być maja czasy wiecnymi [...] A miesckie sprawy prawa majdeburskiego albo jakiegokolwiek innego wezwania ludzi wedle obyczaju koronnego przez urzedniki nasze koronne $i$ dworu naszego $w$ tych sprawach $i$ potrzebach ich do nas $i$ do dworu naszego przypadajace będq polskim pismem odprawowane; Akta unii Polski z Litwq (1385-1791), wyd. S. Kutrzeba i W. Semkowicz, Kraków 1932, nr 136, s. 305. Taką widocznie stosowano dotąd na Wołyniu praktykę, której król obiecywał przestrzegać dalej: w sądach miano posługiwać się bądź językiem ruskim, bądź polskim; niemiecki nie wchodził $w$ rachubę w ogóle, nikt go tam nie znal!

75 Przypomnijmy domysł J. B ardacha: polska ława $\mathrm{z}$ polskim sołtysem stosowała zapewne nadal polskie prawo zwyczajowe, które znali ławnicy z tradycji; wypowiedź zaopatrzona wszakże dodatkiem: uzupetniają je tylko elementami stanowego prawa niemieckiego (op. cit., s. 277); zauważ też na s. 163 passus następujący: dokument ten [lokacyjny] zapewnial osadnikom możność używania sqdowego prawa niemieckiego, a na s. 196-197: jego [dokumentu lokacyjnego] zasadniczym punktem bylo wylaczenie mieszkańców wsi spod mocy obowiqzujqcej prawa pospolitego $i$ nadanie prawa niemieckiego. 
11.3. Komplikacje następowały również $\mathrm{z}$ innego powodu. Nie skłonniśmy sądzić, by w Polsce, nie wyłączając i dzielnicy śląskiej, istniały wsie czysto niemieckie. Moglo, co prawda, tak zdarzyć się nieraz przy lokacji in cruda radice, aus der grünen Wurzel. Wszakże to chyba zjawisko nieczęste. A nawet gdy ono miało miejsce, od samego początku nowi, obcy osadnicy, kontaktowali się z okolicznymi wsiami, zamieszkanymi w masie przez tubylców, a zatem Polaków. I z nimi wchodzili w spory. W tym wypadku sąd był $w$ calości niemiecki (soltys $\mathrm{i}$ lawa), natomiast podsądnymi byli i Niemcy i Polacy. Że tak było w rzeczywistości, dowodzą przytoczone niżej przykłady.

11.4. Przyjrzyjmy się najstarszej zachowanej księdze lawniczej - registrum scabinorum in Croschin ${ }^{76}$, interesującej $\mathrm{z}$ następujących racji. Nie mamy żadnych wątpliwości co do narodowego składu nowo wybranej w $1408 \mathrm{r}$. ławy. Oto miana jej siedmiu członków: (1) Henricus Meysner, (2) Ruffus Close, (3) Schon Matis, (4) Heynusch, (5) Nico, Fater Zele, (6) Michel Schuler, (7) Iakuschz Tewbener (nr 1027). To niewątpliwie Niemcy! Niemieckie miana lawników pojawią się również później, np. nr 1080 (r. 1419), nr 1105 (r. 1420), nr 1607 (r. 1439). I w tych latach przez chlopów-Niemców lawa obsadzona. Niemcem musiał być zatem i soltys. Taki komplet sądził - mniemalibyśmy - według prawa niemieckiego. Nie ulega to wątpliwości, gdy spór toczyli z sobą Niemcy. Oni nawet w przeważającej liczbie występują w powołanej księdze jako podsądni. To naturalne; przykładów bezlik. - Atoli, czy na rozprawach sądowych w Krościenku nie jawili się również Polacy?

11.5. Posłuchajmy: et interrogavit Polonos et Thewtunicos, parvos et magnos (Kroś. nr 1453 r. 1432); et convocavit totam communitatem, iuvenes et senes, parvos et magnos, Polonos et Tewtunicos (ibidem, nr 1555, r. 1437); item Pesch Kraws [...] interrogavit totam communitatem, utrum aliquis esset tam inter Dewtunicos quam inter Polonos, qui vidisset [...]; extunc tota communitas. Dewtunici et Poloni regraciabantur sibi et toti familie sue, dicentes [...] (ibidem, nr 1691).

Ale to nie wszystkie wskazówki świadczące o obecności Polaków na rozprawach $w$ niemieckim sądzie wiejskim.

11.6. Spotykamy również tamże wypadki przydomka Polak: Bernhart Polonus (nr 1072); Polensch Lorencz, Polnesch Hernche (nr 1817); Hannus Poler: (nr 2329); Ioannem Polen (nr 2330); Hannusz Polen (pięciokrotnie, obok Iohanni Polen, nr 2538); Hannusz Polen (dwukrotnie, $\mathrm{nr} 2540$ ); laboriosum Iohannem Polen (nr 2586).

${ }^{76}$ SPPP, t. 11, s. 147. 
11.7. Przyjrzyjmy się dalej mianom osób notowanych $w$ protokolach tegoż sądu: Petro Czerhalthouicz (nr 1048); Vernko (nr 1049); Stanko et Micko (nr 1051); Iacobus Glamb (nr 1067); Nicolaus dictus Ianchin (nr 1076); Stanislaus (nr 1079); Stanislaus Schindeler (nr 1089); Świetoslaw, Rakowski (nr 1196); Thomko, Paschonis Furman filius (nr 1697); Pascho Furmans zon (nr 1698-1699); erga Thomkonem, filium Furman (nr 1701); Marczin Iachnik (nr 1707); Iaschko de Trzesnow, Laurencius alias Wawrschko (nr 1713, tenże ponownie w nr 1721: Wawrsko, Maczke Zambern (Sambr) (nr 1734, 1735); ponownie w tekście niemieckim!); Iohannes alias Iachnik molendinator (nr 1738); Iohanni Bartosch de Hoczew (nr 1750); Mathias Woynak (nr 1764, nr 1777 zapis: Wonak); Kosczel (nr 1777); Iohannes Iwan (nr 1780, ponownie $\mathrm{nr} 1790,1792$ ); Ian Czonski (nr 1782 zapis z przekreślonym o, w nr 2185); Czonsky Ian, apud Stankonem Schadi; Urbanus [...] pro fratre suo dicto Woytek (nr 1796); Warschko (nr 1798); Margaretha olim Mathie Voytchyn (nr 1811); a Iohanne Woynak (nr 1812); Petro Brodka (nr 1816); Iacobus Straltkofski (nr 1822); Laurencius alias Waverzen (nr 1828); Brathos (nr 1829-1830); Wassil (nr 1866); Climko Gemsa (nr 1870); Stanko (nr 1876); Nicolaus Urbanowicz, Stanko Olee (nr 1967, także w nr 2051, 2114; w nr 2291 sororini Nicolai Urbanowicz), (Stanko jeszcze później parokrotnie, ale też w postaci zlatynizowanej); Staskoni Olee (nr 1972, nr 1984: Stanislaum Olee), Stanko Gemza (nr 1984); Iachnik (nr 1990); Sczensky Ian (nr 1999); Koszel Ian, ( $\mathrm{nr}$ 2000, w nr 2331: filia Iohannis Koszyel); Wawrzek de Dubeczko (nr 2001); Ian Golecz (nr 2019); Ian Sombrowicz (nr 2022); Iohannes Bortesch, (nr 2034, ponownie Hannus Bartosch nr 2140); Iokel Bartosch (nr 2100); Petro Twork (nr 2116, ponownie nr 2117); Michael Gelcyn Cochnowycz (nr 2401); Mathias Zombek, filius Iohannis Kochen (nr 2278); Iohannes alias Ianko (nr 2314); frater Stanko (nr 2331); Iacub Chozel (nr 2334); Mathia Costek (nr 2346); Martinus Rosdarlo de Chelnica ( $\mathrm{nr}$ 2356), Martinus Isdarsylo de Chmelnycke (nr 2358), primus Lorkovsky Czyemny (nr 2415, dwukrotnie); nomine Laurencium Czyemny ( $\mathrm{nr} 2421)$; Loryncz Czyemny (nr 2510); Iohannes Czyesky (nr 2430, tamże: Czyesky Hannusz, Ian, Czyskyemu Yanovy; Ian, Yan Czyeszky nr 2434, 2436), duo homines de Ixkrzyna, primus Petrus Pudelko, secundus Gurek Clymeczcowycz (nr 2434); Alberto Tarnowskyemu (nr 2437); Stanislaus Oley (nr 2447 ponownie nr 2452, 2471), Andree Kyelarovy et Hannusovy, ipsius filio (nr 2484); laboriosus Woytek, filius Oley (nr 2491 trzykrotnie), Woytek (nr 2492 dwukrotnie); Hannusowy Swestrowy, Hannusz Suster (nr 2497, Hannusz Swster, Hannusowy Sustrovy, Hannusz Suster nr 2499), Maczek Tworkowycz obok Maczek Thworkonis (nr 2532); Staszek de Malynowka, filius Matyszkonis (nr 2536); Mathias Nowak (nr 2543); Gurek Czemny, Gurk Hanel (nr 2545, powtórzenie nr 2546); Martinus Gyodlovsky (nr 2549). 
Toż to wszystko miana używane tylko przez Polaków. A jest ich naprawdę niemało! Nawet gdy nazwisko jest niemieckie - Szuster, jego polska deklinacja jest symptomatyczna. Czyżby Niemiec nazwiskiem Schindeler nosił imię Stanislaw? Synem Furmana jest Paszko, a Jana Kochen - Maciej Zombek!

11.8. Charakterystyczne też polskie postacie imion kalendarzowych występujących przed sądem dziewcząt: Nastka (nr 1733 - w tekście niemieckim!). Kachna obok Katherina ( $\mathrm{nr} 2125,2556)$; alia Kasza virgo ( $\mathrm{nr} 2570$ ), co odczytamy jako Kasia. Trzy hipokoristika czysto polskie!

11.9. Do przytoczenia również miana żon, derywowane od nazwisk ich niemieckich mężow: Elizabeth Szymonova (nr 2426); Kyszwatrowa (nr 2551 dwukrotnie); Kyelarova, Andryssova (nr 2555); veniens honesta Margaretha vidua Hanuszowa Tymnarowa (nr 2588); raz w przypadku zależnym: procurator Margarethe Tymmayerowey ( $\mathrm{nr} 2558$ ).

Takiej formacji Niemka $z$ pewnością nie użyłaby nigdy! To były polskie dziewczęta, które wyszły za mąż za niemieckich chłopców - Kielara czy Andryssa, czy Tymmayera. Przykładów - prawda - niewiele, ale też kobiety pojawiają się $w$ sądach nieporównanie rzadziej aniżeli mężczyźni. - Zresztą te malżeństwa mieszane, $\mathrm{z}$ miłości lub $\mathrm{z}$ konieczności (brak kandydatek rodaczek), przy tym samym katolickim wyznaniu kontrahentów, przy równoczesnym braku dziewiętnastowiecznego narodowego szowinizmu, thumacza gwaltowne tempo, w jakim polonizowały się $w$ morzu polskim grupki niemieckich osadników.

11.10. Charakterystyczne też, że $w$ protokołach pisanych $w$ zasadzie po łacinie - aczkolwiek niemało też sformułowań niemieckich - pojawiają się nie tylko wyrazy niemieckie, ale także ich odpowiedniki polskie: ćwiertnia; (nr 1597 r. 1438), pro agro communitatis, dicto Viweyg alias scotknicza (nr 1661, r. 1440). Zrazu - co prawda - nieczessto. Wszakże od roku 1467 polskie inkrustacje stały się niemal regułą: quia disposuerunt vulgariter szacowaly hi prudentes viri adiurati, [...] szacowaly hereditatem [...] pro sedecim marcis ( $\mathrm{nr} 2408$ ); perdere vulgariter foldrovacz ( $\mathrm{nr} 2410$ ); sed invadiavit sibi in vadium, vulgariter zaclath (2413, ponownie: $\mathrm{nr} 2580$ ); et ipse Pelczar invadiavit sibi alias szaclath in sex septimanis); sine omni dilacione vulgariter besz szudnye wlky yszthne pyenudze (nr 2417); lucrata est per suum procuratorem [...] duplex qwath [...] Et super hoc duplicem qwath fideiusserunt (nr 2421) ${ }^{77}$; Et super hoc domini iurati susceperunt alias

${ }^{77} \delta_{\mathrm{w}}$ polski wyraz pojawia się jeszcze parokrotnie: lucrata est unum quath (nr 2422); Yan Czyesky remansit Martino Pelczar gwath ad longum tempus [...]. Et super hoc Yan Czyeszky vocatus est ad dominum capitaneum ad longum tempus ( $\mathrm{nr} 2436$ ); quia tenetur solvere domino Loryncz, sculteto, alias qwath [...], quam iste debet solvere alias qwath, ius sibi decrevit 
folk $^{78}$, domini viceadvocati (nr 2555); ad conspiciendum illum inclusum in truncum alias gyathego [...] ipsi fideiussores venerunt ad eundem retentum alias gyaczcza; idem retentus clamavit ad Laurencium scultetum: a hev me, anye stoy tysz ad scultetum, hic mihi fecit iniuriam, recepit michi alias coly et rethe, quibus ego vanavi pisces in fluvio appreciato ( $\mathrm{nr} 2562$ ); concordate sunt cum suo alias oczczymem [...] sic concocordate sunt idem due sorores omnia alias sczebrzchwy a Laurencio Fox $\mathrm{nr}$ 2570; alias czyesc $z$ domini Georgii, [...] in ipsius bonis alias gymyenye ( $\mathrm{nr} 2584$ ); et super nullum iuratum habeo hoc repetere alias spomynacz ( $\mathrm{nr} 2586$ ); susceperunt illam concordiam alias szaczowanye, quam concordiam fecerunt ( $\mathrm{nr} 2588$ ) habet solvere fertonem pro alias za sczebrwch [...] tunc sibi habet persolvere in primis zasczebrwch (nr 2590).

11.11. Obok przytoczonych pojedynczych wyrazowych inkrustacji polskich pojawiają się, choć znacznie rzadziej, pełne polskie zdania: Et idem Szwyaszek suscepit hoc alias poddalszye yest yemu tali suscepcione ( $\mathrm{nr} 2584)$; quia idem Hannusz obligatus est tutor esse, alias obwyaszal szye yest oppyekaldnykem bycz sex puerorum (nr 2589).

11.12. Co więcej, na rozprawach posługiwano się nie tylko językiem niemieckim, ale i polskim: et post hoc iudex iuratus simili modo interrogavit communitatem ter, bis vulgariter (tzn. po niemiecku) et tercio - polonice, utrum ullus dedit sibi culpam [...] (nr 1658, r. 1440) ${ }^{79}$; item Cloze Schubert, molendinator in Crosczenko, in iudicio bannito interrogavit totam communitatem deutunice et polonice (nr 1838, r. 1444).

Zakładając, że wspomniani w protokołach lawnik i Schubert czuli się jeszcze Niemcami, pewne jest, że zdążyli się już nieźle poduczyć polskiego!

11.13. Communitas, gminę Krościenko, tworzyli zatem i Niemcy, i Polacy, choć pierwsi zmonopolizowali w swym ręku miejscowe sądownictwo. Widocznie oni stanowili grupę właścicieli nieruchomości chłopskich lepiej sytuowanych majątkowo. Ze stosowaniem prawa w przedstawionych wyżej sytuacjach rodziły się chyba niejednokrotnie trudności. Czy nie brano pod uwage narodowości podsądnych, jeśli byli nimi Polacy? Czy nie ich prawo osobiste było dla wyrokujących miarodajne?

ad longevum diem ( $\mathrm{nr}$ 2574). Notuje się go zwykle ze znakiem zmiękczenia, kwyath, choć parokrotnie też bez niego. Wydawca drukuje ów termin stale dużą literą na skutek tego nie uwzględnili go ekscerptatorzy StStp, w którym znalazł się tylko kwiat w znaczeniu rośliny kwitnącej czy jej części.

${ }^{78}$ Wyraz ten powtórzony wielokrotnie, częściej z czasownikiem facere - et super hoc iurati fecerunt alias folk ( $\mathrm{nr} 2560$ ); tak samo $\mathrm{nr} 2561,2563,2565,2566$. Notuje go SłStp.

79 Zauważ przewage języka niemieckiego: dwa razy po niemiecku, raz po polsku. 
12.1. W powyższych wypadkach występowały różne narodowości i po stronie sądu, i po stronie podsądnych. Dochodzić zatem musiało do konfliktu praw. Tak by to się wydawało historykowi-absolwentowi wydziału prawa. Jednakowoż można się zastanowić, czy problem, jakie stosowano prawo $w$ razie podobnego konfliktu - niemieckie czy polskie - nie jest problemem czysto akademickim. Toż cały komplet sędziowski - zarówno przewodniczący, jak i przysiężni byli prostakami bez jakiegokolwiek teoretycznego przygotowania prawniczego. Do spisów praw nie zaglądali z pewnością, ponieważ byli analfabetami. Liczyć się też musieli z poczuciem sprawiedliwości podsądnych - zarówno Niemców, jak i Polaków. Czy zatem stawiana przez historyka kwestia stosowania $w$ ich orzecznictwie takiej (niemieckiej) czy innej (polskiej) consuetudo była w ogóle aktualna?

12.2. Wiejscy lawnicy - jak się wyraża niedwuznacznie Groicki - z glów sqdzili, a nie według jakiegoś prawa, kierowali się zatem jedynie zdrowym chłopskim rozsądkiem. Scabini, jak i scultetus - wszyscy analfabetami - wyrokowali zgodnie $z$ własnym sumieniem, przyświecała im jedynie zasada shuszności! Zaryzykowalibyśmy najchętniej tezę: dla wszystkich chłopskich sędziów miarodajna była jedynie aequitas. To kryterium wydaje się nam ze wszech miar najwłaściwsze ${ }^{80}$. Tym samym dla tychże ludzi problem konfliktu praw nie istnial w ogóle. Soltys był kompetentny we wszystkich sprawach - i polskich, i niemieckich, jak tego dowodzi przyznanie mu jednej trzeciej kar sądowych de omni re iudicata Polonicali, Theutonicalique (KDWP 7 nr 449 r. 1402), de qualibet re iudicata, sive Theutonicali, sive Polonicali (ibidem nr 537, r. 1404), de omni iudicio, Theutunicali sive Polonicali iudicatis seu iudicandis (ibidem, nr 538, r. 1404). Takiż sam walor przypiszemy zwrotowi: tertium denarium omnis iudicii, quod ibidem iudicatum fuerit, et cuiuslibet penae, quae veniet de iudicio memorato (ibidem, $\mathrm{nr} 510, \mathrm{r}$. 1404). Praktycznie chłopski komplet sędziowski nie orientował się we wskazanych subtelnościach prawniczych. Zatem i historyk winien przejšć nad nimi do porządku dziennego. - Ostatecznie, idąc na kompromis, powiedziałby: wyroki sądów lawniczych opierały się na słabo sprecyzowanym, zwyczajowym prawie ani niemieckim, ani polskim, lecz po prostu... wiejskim.

13.1. Stwierdźmy, czy lawnicze księgi wiejskie nie wypowiadają się również w kwestii prawa stosowanego w sądach wiejskich. Przyjrzyjmy się wpierw normom proceduralnym: Super hoc idem Nicolaus posuit solidum scabinorum

${ }^{80}$ Por. informacje z 1488 r.: ...ad quod iudicium veniens lohannes voce alta, sonorosa ac intelligibili voce, stans, dixit se nichil mali scire de viceadvocato et scabinis suprascriptis, nisi omne bonum et quod ipsi michi aut sibi iuste iudicant et aliis, tam divitibus quam pauperibus, iuxta eorum conscienciam et iuramenta, tamquam boni et iusti homines; super hoc Iohannes Boc posuit ius scabinale (Komb. nr 74). 
[...] iuxta consuetudinem iuris Theutunici (T. nr 75, r. 1445); Et hic dictus $N$. ius scabinorum posuit iuxta ius Teutonicum (Wara, nr 67); Et in hoc ius scabinorum in testimonium posuit secundum ius Teutonicum (ibidem, $\mathrm{nr} 68$ ); posuit ius scabinorum iuxta ius Teutonicum (ibidem, $\mathrm{nr} 70$, r. 1467) ${ }^{\mathbf{8 1}}$.

13.2. Et idem prefatus Wasyl resignavit prefato Petro coram eodem iudicio, ramo porecto, semel, secundo, tercio, quarto, et preter iudicium proclamatum est iuxta formam iuris Teutonici (T. nr 109, r. 1483). Resignaverunt [...] ramo, ut est mos in Theutunicali iure (ibidem, nr 124, r. 1489).

Prawdopodobnie tutaj należy również tekst następujący: sibi resignavit secundum ius Teuthunicale (chodziło bowiem i tu o sprzedaż pola, T. nr 125, r. 1489).

13.3. Qui supradicti, moniti a iure secundum ius Theutonicum, omnia deliberaverunt (T. nr 569, r. 1515).

13.4. Quis Voythany fuit requisitus bis, ter, quot portat ius Almanicum (T. nr 603, r. 1520), qui supradicti fuerunt requisiti bis, ter secundum ius Almanicum (ibidem, $\mathrm{nr}$ 623, r. 1522); que partes fuerunt requisite bis, ter secundum ius Theutonicum (ibidem, nr 705, r. 1529) ${ }^{82}$. Quis Mathias [...] fuit requisitus bis, ter; id, quod ius Theutonikum tendet (ibidem, nr 707, r. 1529).

13.5. Idem prefatus Wasyl resignavit prefato Petro coram eodem iudicio, [...] semel, secundo, tercio, quarto, [...] iuxta formam iuris Teutonici (Wara nr 109, r. 1483).

13.6. Et preter iudicium proclamatum est iuxta formam iuris Teutonici (ibidem, nr 109, r. 1483).

13.7. (Oskarżony o kradzież pieniędzy) de eadem pecunia a iure appriopriata illum fecerunt, prout ius Theutunicale decrevit, iustum ac innocuum (T. $\mathrm{nr} 71$, r. 1442). In quo iudicio [...] publice in iudiciis constitutus primo, secundo, tercio, quarto se expurgando et suam conscienciam et dicendo: „domine iudex! ego me constituo coram iudicio et facio satis iuri; si quis contra me habet aliquid loqui, ego ad ipsum respondere volo". Quod et notum fecit in iure scabinorum mediante iure Teutonico [...] Et est tanquam unus in communitate bonus et bene conservatus. Quod probat tota communitas (Wara nr 66, r. 1467); publice astando et comparendo, mediante iure Theutunicali, iudicia quaiuor, iudicium penes iudicium, se expurgando et conscienciam suam (ibidem, nr 67, r. 1467) ${ }^{83}$.

81 Wszakże spotykamy również takie uzasadnienie: postit ius scabinale secundum formam iuris (Komb. nr 53, r. 1481). Najczęściej jednak bez żadnej motywacji: posuit ius scabinale.

82 Dalej czytamy: Ipse predicte partes fuerunt requisite bis, ter, usque quartum. Tu już nie zaznaczono, że to właściwość prawa niemieckiego, jak zresztą $w$ tylu innych wypadkach, których bezlik.

${ }^{83}$ Ale już w 1500 r. pojawia się takie uzasadnienie oczyszczającej procedury: sicut est mos in Regno Polonie (Komb. nr 99)! 
13.8. Oto zestawienie wypadków postępowania, zgodnego z prawem niemieckim: 1) sądowi składa się opłatę - schöffenschiling; 2) rezygnacji dokonuje się za pomocą (zielonej) gałęzi; 3) sąd wzywa strony do rozważenia zamiaru dokonania transakcji; 4) sąd kieruje trzy-, a nawet czterokrotnie pytania do zbywcy nieruchomości, czy rzeczywiście zgadza się na sprzedaż; 5) zbywca czterokrotnie oświadcza swą zgodę na transakcję; 6) wyrok ogłasza się publicznie, także poza izbą, w której toczyło się postępowanie; 7) oczyszczanie honoru chłopa dokonuje się poprzez jego czterokrotne stawiennictwo przed trybunakem wiejskim, a przy tym - domyślne - nie zjawi się oskarżyciel, który by podtrzymał swój zarzut, et quia contra eum nullus quidquam locutus est, idem Gregorius expurgavit innocenciam suam (T. nr 87, r. 1447).

13.9. Zgodziliśmy się na to, że wkład prawa niemieckiego zasadzał się na wprowadzeniu samorządnego ustroju sądowego (lawa wyrokująca $z$ głosem stanowczym pod przewodnictwem soltysa). Natomiast niemieckość stosowanej procedury budzi poważne wątpliwości, mimo przytoczonych wyżej tekstów. Nasuwa się bowiem pytanie, czy takie samo postępowanie nie było współcześnie właściwe również innym trybunałom, m. in. także polskim. Wszystkie czynności, które zestawiliśmy wyżej w 7 punktach, praktykowano chyba w każdym sądzie średniowiecznym. A już $z$ cała pewnością - ograniczamy się do najjaskrawszego przypadku, którego chyba nikt nie zakwestionuje: w sądach polskich czy niemieckich, jak wszędzie, pobierano opłatę sądową! Co więcej, nazywała się ona tam, w sądzie polskim (!), nie tylko memoriale, ale również solidacio alias schepszelnyk! ${ }^{84}$ Wszakże to już nie kwestia niemieckiej instytucji, lecz zapożyczenia terminologicznego, świadczącego o mocnej pozycji języka niemieckiego w Polsce, o dużym jego autorytecie! 85 - A jak się przedstawiała sprawa stosowania niemieckiego zwyczajowego prawa materialnego, prywatnego i karnego?

\subsection{Oto informacje $\mathrm{z}$ zakresu prawa materialnego:}

14.1.1. Sprzedawca gruntu - Piotr Paczola, otrzymując zapłatę czéścia gotówką, częścią ratami, które będą splacone w przyszłości, liberavit dictum Nicolaum (nabywcę) a qualibet persona secundum ius Teutunicale et iam liberum fecit a se et a suis pueris et propinquis, quicunque fuerit seu quilibet ipsorum (T. nr 355 r. 1483).

14.1.2. Hii tres coniuncta manu fideiuberunt annum et diem secundum iu: Teutonicum, ipsum intercedendo ex omni parte et ex omni impedimento (Wara nr 69, r. 1467). Sądzimy, że powołanie się na prawo niemieckie dotyczy tu obowiązku intercesji przez rok i dzień, a nie rękojemstwa pospólną ręką.

84 J. R a f a cz, op. cit., s. 183-184.

85 Zwracaliśmy na to uwage na innym miejscu, Wojciech-Adalbertus, s. 91, 103. 
14.1.3. Chcqc pokazać bliskość swa wedlug prawa opisanego majdeburskiego (Wara $\mathrm{nr}$ 332, r. 1601).

14.2. $\mathrm{Z}$ zakresu prawa materialnego - widzimy - mamy wskazówek znacznie mniej niż poprzednio. Ale $\mathrm{i} w$ nich również niełatwo dopatrzeć się jakichś odrębności niemieckich. Jest bowiem rzeczą rozumiejącą się samo przez się, że sprzedawca rezygnuje $\mathrm{z}$ własności sprzedanego obiektu (14.1.1.), że zobowiązuje się do intercesji przez rok i dzień (14.1.2.), a od rezygnacji czy wylączeń z prawa bliższości (14.1.3.) - tekst zresztą bardzo późny! - w aktach polskich aż rojno; $i$ to bez jakiegokolwiek związku $z$ prawem niemieckim. Jaki $\mathrm{z}$ tych obserwacji wysnuć wniosek?

15.1. To wszystko zupełnie nie przeszkadzało przekonaniu uczestników gajonego sądu wiejskiego, ze stosuje się w nim prawo niemieckie. Przecież to sąd niemiecki! Mniemamy, że pogląd ten był powszechny, wlaściwy nie tylko skrybie, który redagowal protokoły, ale całej społeczności wiejskiej. Pisarz, jedyna $w$ gronie analfabetów osoba wykształcona, wyrażał z pewnością przekonania ogółu.

15.2. Zresztą powoływanie się na prawo niemieckie dodawało autorytetu samemu sądowi, a zatem i jego wyrokom, podobnie jak łacina w kościele! To, co niezrozumiałe, nabiera snadnie cech szamańskiego zaklęcia. A przy tym można było śmiało powoływać się na ius Teutonicum. I tak go nikt $\mathrm{z}$ obecnych nie znał! Powtórzymy tu ponownie przytaczaną $w$ innych kontekstach wypowiedź źródel: iura Teutonica erant penitus incognita!

16. Przedstawmy generalny wynik naszych roztrząsań. Ponieważ wiejskie lokacje iure Teutonico w przemożnej liczbie wypadków dotyczyły ludności miejscowej, zatem polskiej, ta zaś zwyczajowego prawa niemieckiego, materialnego $\mathrm{i}$ formalnego nie znała notorycznie, zatem do jego stosowania nie dochodziło praktycznie nigdy, bo dojść nie mogło! Konkluzja zatem oczywista, aż zastanawiająca swą oczywistością: $\mathrm{z}$ reformą rolną iure Teutonico zwiążemy wprowadzenie samorządnego sądownictwa wiejskiego, niemieckich sądów ławniczych, acz pozostających dalej pod ręką pańską, jak we wszystkich włościach immunizowanych. Nie dokonano natomiast równocześnie zmiany prawa materialnego $\mathrm{i}$ formalnego ${ }^{86}$. Do czego zresztą było ono chłopom polskim potrzebne? Niemieckie prawo na polskiej ziemi znal mało kto poza cudzoziemcem-Niemcem, cystersem, sołtysem lub chłopem. Wśród polskiej ludności wiejskiej - akcentujemy po raz n-ty - iura Teutonica erant penitus incognita! Siłą rzeczy w sądownictwie kmiecym posługiwano się dalej - tak być musiało - zwyczajami polskimi. Nie pomoga tu nic zapewnienia

${ }^{86}$ Już B. Zientara pisał, że niemieckie zwyczaje prawne na wsi polskiej znajdowały zastosowanie ,äußerst selten" (Die Bauer, s. 33). 
skrybów o stosowaniu prawa niemieckiego. Wsie założone na tym prawie, lecz zasiedlone przez Polaków, iure Polonico se regebant. Konkluzja nasza sprzeczna $\mathrm{z}$ tym, co głosi nauka niemiecka o Einwurzelung des deutschen Rechtes in den neugewonnenen Gebieten ${ }^{87}$. Zgadzamy sią natomiast $\mathrm{z}$ wynikami znakomitego studium L. Lysiaka: leitmotivem jego dzieła przekonanie o nieznajomości niemieckiego prawa w Polsce czy niezdolności jego praktycznego zastosowania, $i$ to w całym sądownictwie, nawet najwyższym ${ }^{88}$.

Tak było na wsi polskiej w średniowieczu ${ }^{89}$. A w dobie nowożytnej? I temu zagadnieniu należałoby przyjrzeć się bliżej ${ }^{90}$.

${ }^{87} \mathrm{H}$. Con rad, Die mittelalterliche Besiedlung des deutschen Ostens und das Deutsche Recht, „Arbeitsgemeinschaft für Forschung des Landes Nordrhein-Westfalen. Geisteswissenschaften" [Köln und Opladen] 1955, Heft 35. Autor artykuh, znany ze wspaniałej dwutomowej syntezy Deutsche Rechtsgeschichte (dysponujemy jej wydaniem drugim z 1962-1966), pisze o Bedeutung des deutschen Rechtes für die Ostkolonisation (s. 7), czemu nie zamierzamy przeczyć. Odnosimy wszakże wrażenie, iż nie rozróżnia on dokładnie ius Teutonicum jako prawa osadniczego (Siedlerrecht), stwarzającego posadę chłopską, od prawa niemieckiego sądowego, a tymczasem to rzeczy zgoła różne. Tę dystynkcję uważamy za nieodzowną przy rozważaniach nad prawem niemieckim w średniowiecznej Polsce. Gdy chodzi o prawo osadnicze, zgodzimy sie z teza powołanego autora: ...es wurde sogar zum begehrten Recht der eingesessenen Bevölkerung (s. 25), tylko że instytucja własności podzielonej nie była wynalazkiem niemieckim! Nie sądzimy natomiast, by można powiedzieć, iż w równym stopniu polscy chłopi pożądali sądowego prawa niemieckiego. Ono było po prostu im nieznane. Stanowisko autora zresztą nas nie zdumiewa; studium jego nie zawdzięcza bowiem swego powstania własnym badaniom, ono nie ,eine eigene Forschungsarbeit wiedergibt, sondern die Ergebnisse der historischen und rechtshistorischen Wissenschaft nur zusammenfassen und unter großen Gesichtspunkten zeigen will" (s. 8). Czytelnik jego artykułu odnosi wrażenie, że autor nie tylko nie mial w swym ręku żadnego privilegium sculteti, ale nie znał zupełnie literatury polskiej, co musiało się odbić ujemnie na jego wywodach.

${ }^{88}$ Por. naszą recenzję CPH, t. 44, s. $168-173 . \mathrm{K}$. K a mińs k a wyraziła się tak: Mniejszq wage przywiqzywano do prawa, na podstawie którego orzekaly sqdy (op. cit., s. 48). - Dorzucmy, że przywilej fundacyjny Kazimierza Wielkiego wypomina zwracanie się o pouczenia ad partes remotas Rynenses, in Maydeburg ciuitatem (op. cit., s. 171). O orientacji geograficznej autorów dokumentu nie świadczy to szczególnie, Magdeburg w Nadrenii!

${ }^{89}$ Naszą intencją nie było w żadnym razie den Begriff Deutsches Recht umdeuten oder gar verfälschen, um die Leistung der deutschen Kolonisation entwerten zu können; H. Co n $\mathrm{r}$ ad, op. cit., s. 8. - A jak wythumaczyć fakt, że w olbrzymiej masie wypadków przywileje, nadające prawo niemieckie, przewidują dla nowo zakładanych osad miana polskie (por. J. M a t u s ze wski, Materialy do nazewnictwa osad lokowanych na prawie niemieckim $i$ woloskim), RKJ 1973, 1. 19, s. 75-98; tenże, Materialy do nazewnictwa osad lokowanych na prawie niemieckim (uzupelnienie), RKJ 1977, t. 23, s. 123-128. (W przygotowaniu zestawienie dalsze).

90 Zdumiewa wiara przedrozbiorowych prawników polskich, od redaktorów statutów Kazimierzowskich począwszy, w obowiązywanie prawa niemieckiego na wsi polskiej, w oparciu o wyrażenie ius Teutonicum dyplomów lokacyjnych, wyrażenie - jak skonstatowaliśmy - mające całkiem inny walor. Co przy tym szczególnego, objęto tą recepcją wszystkie wsi, nawet te, które nigdy na prawie niemieckim nie były lokowane! Że to recepcja nader powierzchowna, wykazał w swym głośnym studium Ludwik Lysiak. 